\title{
Molecular and morphological phylogenetics of chelonine parasitoid wasps (Hymenoptera: Braconidae), with a critical assessment of divergence time estimations
}

\author{
Rebecca N. Kittel ${ }^{1,2} *$, Andrew D. Austin ${ }^{1}$, and Seraina Klopfstein ${ }^{1,3}$
}

\author{
${ }^{1}$ Australian Centre for Evolutionary Biology and Biodiversity, School of Biological Sciences, \\ The University of Adelaide, Adelaide, SA,5005, Australia \\ ${ }^{2}$ current address: Laboratory of Insect Biodiversity and Ecosystems Science, Graduate \\ School of Agricultural Science, Kobe University, Rokkodai 1-1, Nada, Kobe, 657-8501 Japan \\ (*Corresponding Author. E-Mail address: rebecca.n.kittel@gmail.com) \\ ${ }^{3}$ Naturhistorisches Museum Bern, Bernastr. 15, CH - 3005 Bern, Switzerland
}

\begin{abstract}
Parasitoid wasps of the subfamily Cheloninae are both species rich and poorly known. Although the taxonomy of Cheloninae appears to be relatively stable, there is no clear understanding of relationships among higher-level taxa. We here applied molecular phylogenetic analyses using three markers $(C O I, E F 1 \alpha, 28 S)$ and 37 morphological characters to elucidate the evolution and systematics of these wasps. Analyses were based on 83 specimens representing 13 genera. All genera except Ascogaster, Phanerotoma, and Pseudophanerotoma formed monophyletic groups; Furcidentia (stat. rev.) is raised to generic rank. Neither Chelonus (Chelonus) nor Chelonus (Microchelonus) were recovered as monophyletic, but together formed a monophyletic lineage. The tribes Chelonini and Odontosphaeropygini formed monophyletic groups, but the Phanerotomini sensu Zettel and Pseudophanerotomini were retrieved as either para- or polyphyletic. The genera comprising the former subfamily Adeliinae were confirmed as being nested within the Cheloninae. To estimate the age of the subfamily, we used 16 fossil taxa. Three approaches were compared: fixed-rate dating, node dating, and total-evidence dating, with age estimates differing greatly between the three methods. Shortcomings of each approach in relation to our dataset are discussed, and none of the age estimates is deemed sufficiently reliable. Given that most dating studies use a single method only, in most cases without presenting analyses on the sensitivity to priors, it is likely that numerous age estimates in the literature suffer from a similar lack of robustness. We argue for a more rigorous approach to dating analyses and for a faithful presentation of uncertainties in divergence time estimates.
\end{abstract}


Given the results of the phylogenetic analysis the following taxonomic changes are proposed: Furcidentia Zettel (stat. rev.), previously treated as a subgenus of Pseudophanerotoma Zettel is raised to generic rank; Microchelonus Szépligeti (syn. nov.), variously treated by previous authors, is proposed as a junior synonym of Chelonus Jurine; the following subgenera of Microchelonus - Baculonus Braet \& van Achterberg (syn. nov.), Carinichelonus Tobias (syn. nov.) and Scabrichelonus He, Chen \& van Achterberg (syn. nov.), are proposed as junior synonyms of Chelonus; a number of new species names are proposed due to homonyms resulting from the above changes and these are listed in the paper.

\section{Keywords}

Phylogeny, total-evidence, molecular clock, node-dating, Cheloninae, fixed clockrate

\section{Introduction}

Approximately every tenth insect species is a parasitoid which completes its development in or on an arthropod host that is eventually killed in the process (Quicke, 2015). Most parasitoids belong to the order Hymenoptera. The study of parasitoids in general and parasitoid Hymenoptera in particular is critical given that they are a key component of almost all terrestrial ecosystems and comprise one of the most species-rich groups of animals. The Cheloninae are a large subfamily of braconid wasps with approximately 1,400 described species in 17 genera worldwide (Table 1) (Yu et al., 2012; Kittel and Austin, 2014). They are sister to five subfamilies together with which they form the microgastroid complex (Murphy et al., 2008), all of which exploit lepidopteran caterpillars as hosts.

Members of the Cheloninae can be easily distinguished from other Braconidae based on the possession of a complete postpectal carina and a carapace formed by the fusion of the first three metasomal tergites (van Achterberg, 1976; Shaw, 1997).The latter character also occurs convergently in a number of other subfamilies (e.g. Brachistinae, Ichneutinae, Microgastrinae, Sigalphinae), but is generally rare outside of the Cheloninae (Dudarenko, 1974; Quicke, 2015). All chelonines are believed to be solitary koinobiont endoparasitoids especially of larval pyralid and tortricid moths, laying their eggs into the host egg.

Development is then delayed until the host larva emerges, and the parasitoid eventually kills it in the last larval stage (Shaw, 1997). The final instar wasp larva emerges from the host 
larva and feeds from outside before forming a pupal cocoon (Jackson et al., 1978; Huddleston and Walker, 1994). Although some other braconids (a few members of Alysiinae, Helconinae, Ichneutinae, Microgastrinae) also oviposit into host eggs, this strategy is apparently only universal for the Cheloninae (Clausen, 1956; Ruberson and Whitfield, 1996; Quicke, 2015). Chelonines occur on all continents except Antarctica, but the largest number of species are described from the Palaearctic. However, while most genera found in the Palaearctic have a global distribution, numerous genera are apparently endemic to the Neotropics (Table 1) (Yu et al., 2012), while the faunas of the tropics and southern continents are still generally poorly studied.

Although the taxonomy of Cheloninae at the species level is relatively extensive (at least for the Northern Hemisphere) and the generic classification has not changed much during the last few decades (McComb, 1968; Shenefelt, 1973; Huddleston, 1984; van Achterberg, 1990; Zettel, 1992), there is no robust understanding of the phylogeny of the group, which would provide a stable basis for interpreting biogeographic patterns and host associations. Previous attempts to determine the relationships among genera and subgenera were based solely on morphological characters, had limited taxon sampling, and focused only on the Phanerotomini (Zettel, 1990) or Chelonini (Shaw, 1983). Additionally, the Adeliinae have previously been treated as a separate subfamily (Quicke and van Achterberg, 1990; Wharton et al., 1992; van Achterberg, 1993; Shi et al., 2005), but preliminary molecular analyses place them inside the Cheloninae (Belshaw et al., 2000; Belshaw \& Quicke, 2002; Dowton et al., 2002). The current classification is likely further flawed by the weak delimitation of some genera; for example, it remains questionable whether Microchelonus forms a valid genus or is nested within Chelonus (McComb, 1968; Papp, 1995; Lozan and Tobias, 2006; Zhang et al., 2008). In addition, Leptodrepana has been treated as a genus (Shaw, 1983) or, after its synonymy with Ascogaster (van Achterberg, 1990) subsequentely treated as part of Ascogaster (Tang and Marsh, 1994; van Achterberg and Polaszek, 1996; Shaw, 1997; Brajkovic et al., 2010; Yu et al., 2012). To date, no comprehensive phylogenetic analysis incorporating molecular data has been untertaken to resolve key questions concerning relationships within this species-rich and biologically interesting group of braconid parasitoids.

Another open question concerns the age of the subfamily and its constituent groups. Ronquist et al. (2012a) have attempted to date the major groups of Hymenoptera, but they only included very few representatives of the Apocrita and, thus, did not provide age 
estimates for the ichneumonoid families. There have been very few studies that infer the age of braconid subfamilies, with the Rogadinae and Doryctinae (Zaldivar-Riverón et al., 2008a; Zaldivar-Riverón et al., 2008b) and the microgastroid complex (Whitfield, 2002; Murphy et al., 2008) being notable exceptions. These studies have only utilised a node-dating approach, in which a phylogenetic tree is calibrated by assigning fossils (and their ages) to specific nodes as hard minima. There are severe limitations with this method, most of all the sensitivity to the calibration priors (Inoue et al., 2010).

The aims of this study were to use an extensive dataset comprising sequence data from multiple genes and morphology to investigate chelonine relationships, to test the monophyly of genera and tribes, including the position of members of the former subfamily Adeliinae, and to clarify the status of problematic taxa such as Microchelonus and Leptodrepana. Furthermore, we compared three different approaches to infer the age of chelonines: fixedrate dating, node dating, and total-evidence dating, using all described chelonine fossils. The shortcomings of the three methods are discussed both in regard to our dataset and to their application in poorly known groups in general.

N.B. Taxonomic information including the authors of tribes, genera and subgenera are given in Table 1.

\section{Material and Methods}

\subsection{Taxon sampling}

For this study, 83 specimens representing 80 species from all major biogeographic regions, 11 of 17 currently recognised extant genera of Cheloninae, and two of the four recognised genera of the former subfamily Adeliinae were sequenced for three molecular markers (see below; Appendix 1). The alignment included two additional sequences of chelonines obtained from GenBank (Wushenia and Chelonus (Carinichelonus)) (see Appendix 1 for GenBank accession numbers; https://www.ncbi.nlm.nih.gov/genbank/). Four representatives of other braconid subfamilies were used as outgroup taxa, two being members of the closely related microgastroid subfamilies Microgastrinae (Microplitis sp.) and Miracinae (Mirax sp.), one from the Ichneutinae (Ichneutes sp.) which is the sister clade to the microgastroid complex, and one from the more distantly related Euphorinae (Leiophron sp.). 
Genera were identified using the keys from Zettel (1990) and Shaw (1997). For distinguishing between Chelonus and Microchelonus, McComb's (1968) definition was used as follows: female Microchelonus with 16 antennomeres, male with a pit present on the posterior metasoma.

\subsection{Morphological characters, species identification, and fossils}

Thirty-seven morphological characters were coded for all taxa for which we had sequence data (see Appendices 2 and 3). The characters used were mostly adapted from van Achterberg (1984) and Zettel (1990). Character 3 in Appendix 2 ('occipital carina touching hypostomal carina') was identified during the course of this study and was included in the matrix. The program DELTA editor was used to code specimens (Dallwitz et al., 1999).

Sixteen fossil ingroup species representing five genera were used to calibrate the tree in the node dating and total-evidence dating approaches (see Table 2). Morphological characters for these fossil taxa were either examined directly (in the case of Eobracon cladurus Cockerell) or coded based on the original description and images (all others), as the fossil taxa in baltic amber described by Brues (1933) have been lost (Shaw, 1983) or difficult to obtain.

\subsection{Molecular techniques}

\subsubsection{DNA extraction protocols}

Genomic DNA was extracted from specimens that had been preserved in ethanol (75$100 \%)$ or were dry and pin-mounted. One hind leg was removed from each specimen and kept in the fridge for 10 min to let the ethanol evaporate, or a non-destructive approach was applied using the whole specimen. DNA extractions were performed using the Gentra Systems Puregene ${ }^{\circledR}$ DNA Purification Kit (Qiagen). The leg or whole specimen was heated to $55^{\circ} \mathrm{C}$ in a $300 \mu \mathrm{l}$ cell lysis solution with $1.5 \mu \mathrm{l}$ proteinase $\mathrm{K}$ solution. After $12-24 \mathrm{~h}$, excessive proteins were removed by adding $100 \mu$ protein Precipitation solution. The DNA was then washed in $300 \mu \mathrm{l}$ Isopropanol (plus $0.5 \mu \mathrm{l}$ glycogen) and afterwards in $300 \mu \mathrm{l}$ ethanol (70\%). DNA was rehydrated using $50 \mu \mathrm{l}$ DNA hydration solution.

\subsubsection{Gene selection and primer design}


The selected markers included the mitochondrial gene cytochrome c oxidase subunit 1 $(C O I)$ and the nuclear genes elongation factor $1 \alpha$ copy F2 (EF1 $\alpha)$ and 28S rRNA D2-D3 region (28S), resulting in a total of 1,454 bp (444 bp COI, 378 bp EF1 $\alpha$, and 632 bp 28S) (for primers used, see Table 3). All EF1 $\alpha$ sequences were compared with the F1 and F2 copies from the hymenopteran taxa analysed by Klopfstein and Ronquist (2013) and were confirmed to belong to the F2 copy.

In order to obtain sequences from older pinned museum specimens, primers were designed for shorter fragments of $28 S$ (Table 3) using the Geneious Pro v. 5.3.6 (Drummond et al., 2011) (by Biomatters, http://www.geneious.com/) plugin Primer 3 (Koressaar and Remm, 2007). Consensus sequences were created from these shorter fragments and concatenated with Geneious Pro.

\subsubsection{Amplification and sequencing}

We used Eppendorf thermal sequencers for PCR amplifications. Each reaction of $25 \mu \mathrm{l}$ comprised $2.5 \mu 110$ x Taq Gold Buffer, $3 \mu 125$ mM MgCl2, $2 \mu 110$ mM dNTPs, $1 \mu l$ of each forward and reverse $5 \mu \mathrm{M}$ Primer (see Table 3), 0.1 units ( $\mu$ l) AmpliTaq Gold ${ }^{\circledR}$ DNA Polymerase (Applied Biosystems Inc.), and $1 \mu \mathrm{l}$ DNA (approximately $0.2 \mu \mathrm{g}$ DNA). In some reactions, Immolase ${ }^{\mathrm{TM}}$ DNA Polymerase (Bioline) was used. PCR settings started with a denaturation step of $9 \mathrm{~min}$ at $95^{\circ} \mathrm{C}$, followed by 35 cycles of $30 \mathrm{sec} 94^{\circ} \mathrm{C}, 30 \mathrm{sec}$ annealing temp (Table 3), and an extension step of $1 \mathrm{~min}$ at $72^{\circ} \mathrm{C}$. The final extension step was for 6 min at $72^{\circ} \mathrm{C}$. PCR products were purified using the Ultraclean ${ }^{\mathrm{TM}}$ PCR Clean-up ${ }^{\mathrm{TM}} \mathrm{Kit}$ (MoBio Biosystems Inc.) and sequenced by the Australian Genome Research Facility Ltd. (AGRF) using capillary separation.

\subsubsection{Sequence alignment}

The sequences were edited in Geneious Pro and a consensus sequence was created from the forward and reverse sequences. Alignments for each marker were conducted with the Geneious Pro plug-in Clustal W v. 2.1 (Thompson et al., 1994) with the default penalties settings of 15 for gap open costs and 6.66 for gap extend costs. Both COI and EF1 $\alpha$ had open reading frames, and $C O I$ had a typical mtDNA AT bias, and therefore was unlikely to belong to a nuclear copy (Chandra et al., 2006). The concatenated alignment of all three genes was 
then produced using Geneious Pro (alignment available on TreeBase http://purl.org/phylo/treebase/phylows/study/TB2:S17882).

\subsection{Phylogenetic inference}

The morphological analysis, separate gene analyses, concatenated genes analysis, and a combined molecular plus morphological (total-evidence) analysis were each conducted using maximum parsimony (MP), maximum likelihood (ML), and Bayesian inference (BI) approaches. The best-fitting partitioning scheme and most likely substitution model for each partition were identified using PartitionFinder (Lanfear et al., 2012), applying the Akaike information criterion (Posada and Buckley, 2004) (Table 4).

The MP analyses applied a tree-bisection-reconnection (TBR) heuristic approach as implemented in PAUP* (Swofford, 2003), with 1,000 random stepwise addition replicates each holding 100 trees. The characters were treated as unordered and had equal weight. Bootstrap support was calculated in 1,000 iterations, without replicates for the random stepwise addition step.

The ML analyses were conducted in RAxML v. 7.7.0 (Stamatakis, 2006) with 1,000 random starting trees under the GTRGAMMAI model (GTR with gamma-distributed amongsite rate variation and a proportion of invariable sites) (Stamatakis, 2006). Clade support was obtained using 1,000 non-parametric bootstrap iterations, applying fast bootstrapping.

For the BI analyses, MrBayes v. 3.2.2 was used (Ronquist et al., 2012b). Each analysis was run for 20 million generations, with four independent runs of four chains each. Default settings, random starting trees, trees sampled every 1,000 generations, and default heating were used. Topology convergence was verified by a 0.01 threshold of the average standard deviation of split frequencies (Ronquist and Huelsenbeck, 2003), while convergence of the scalar parameters was verified by an effective sample size of more than 200 and the potential scale reduction factor approaching 1 . The first $25 \%$ of generations were omitted as a burn-in.

The analyses were conducted on tizard, the eResearch South Australia high-performance computing cluster (PAUP* and RAxML), or on the CIPRES Science Gateway V 3.3 (MrBayes) (Miller et al., 2010).

\subsection{Dating analyses}


We used three different approaches to infer the age of chelonines: fixed-rate dating, node dating, and total-evidence dating, and assessed the reliability of each method. Because the Bayesian framework allows incorporation of complex age priors, we used BI for the dating analyses, all of which were conducted in MrBayes 3.2.3 (Ronquist et al., 2012b). To make sure that we had large enough partitions for the dating analyses, the molecular data were not partitioned as previously, but a simpler partitioning scheme based on molecular evolution was used instead (Simmons et al., 2006) (Table 4), with the first and second codon positions of both $C O I$ and EFI $\alpha$ forming one partition each, the third codon positions of $C O I$ and $E F 1 \alpha$ each forming another, and $28 S$ represented by a single partition. The fixed-rate analyses were based on the whole gene including the changes at the third codon position of $C O I$, and thus the third codon position was included in these analyses. However, in the node-dating and total-evidence dating analyses, the age of the chelonines became much older due to the high saturation in this partition (data not shown), and hence the third codon positions of COI were excluded. All analyses were run for 50 million generations, sampling every 1,000 generations, using four independent runs with four chains each, and convergence diagnostics applied as detailed above.

\subsubsection{Fixed-rate analyses}

Estimates of the number of substitutions per million years can be used to transform substitution branch lengths into time lengths, at least for more recent time scales. We used the general estimate of the rate of evolution for mitochondrial genes in insects as $2.3 \%$ per million years (Brower, 1994). As the prior on branch lengths might have a strong impact on the resulting estimates, we took two different approaches; first, we used the default clockrate of 1 and only translated branch lengths into time lengths after running the analysis under the default branch-length prior. Second, we fixed the clockrate to the equivalent of $2.3 \%$ for CO1, calculated for our multi-gene dataset using the rate-multiplier values retrieved from the previous run. These analyses are overly naive when compared to the node-dating and totalevidence dating approaches, where we introduced a time-constraint on the root in addition to the information from the fossils. We also ran the fixed-rate analyses with the tree-age prior set as in the two other approaches (Table 5).

\subsubsection{Node dating}


For the node-dating analyses, we used the same multi-gene dataset as for the fixed-rate approach, but calibrated specific nodes according to the ages of fossils. We used offsetexponential priors on two calibration points. Due to the topology of the tree and the fact that most fossils belong to stem-groups within their respective genera, only the oldest fossil Phanerotoma menieri Belokobylskij et al. could be used to calibrate the Phanerotomini clade, as all the other, younger fossils would only have been used to calibrate the ancestor of all chelonines. The minimum age for this group was thus set to $52 \mathrm{Ma}$. As a reasonable mean estimate, we used the age of the oldest fossil of Euphorinae (McKellar and Wolfe, 2010), which was also used to provide the minimum age of the root of the tree (including the outgroups). The mean age of the root of the tree was set to $130 \mathrm{Ma}$ following the estimate for the age of the Braconidae calculated by Whitfield (2002). To test the impact of this arguably subjective prior setting, we varied the means of both calibration node priors among analyses (Table 5).

\subsubsection{Total-evidence dating}

In total-evidence dating, the calibration of the phylogeny is based on fossils included as terminals in the analysis (Ronquist et al., 2012a). To this end, we extended the dataset by including morphological data for the 16 fossil taxa (Table 2), with molecular sequences for fossils coded as missing data. We used a uniform tree prior and the un-correlated gammadistributed relaxed-clock model (IGR). For an initial analysis, the priors on the clockrate (lognorm $(-7.08069,2.458582))$ and on the variance parameter of the IGR model $(\exp (37.12))$ were set as in Ronquist et al. (2012a). After this first step, the IGR variance prior was modified to $\exp (84.65723)$ in an empirical Bayes approach in order to reflect the posterior resulting from this preliminary analysis. The clockrate posterior was very similar to the prior from Ronquist et al. (2012a) and was thus not modified.

The ages of the fossils included as terminals in the dataset were specified according to the ranges of the age estimates of the deposits (Table 2), employing a uniform distribution. Convergence was assessed as above, except the first $50 \%$ of generations were omitted as a burn-in, to improve convergence of the clockrate parameter. Random character exclusion was performed to test whether the number of morphological characters included had an impact on the result. Phanerotoma menieri was the oldest fossil included in the analysis, but in a nonclock, morphology-only analysis ended up further up the tree than the other fossils (not 
shown), and might thus have distorted the analysis. We thus also tested whether the exclusion of $P$. menieri had an impact on the results.

\section{Results}

\subsection{Phylogenetic analyses}

The trees from the ML analyses show an overall similar topology to those of the BI analyses, but with lower support values (Fig. 1). However, the tree from the MP analysis was poorly resolved, which is possibly not surprising given the limitations of this method for analysing multi-gene sequence data (Fig. 1). The Cheloninae plus Adeliinae are recovered in all analyses as monophyletic relative to the outgroup subfamilies, with only the single-gene trees for $C O I$ and $E F 1 \alpha$ not reaching significant Bayesian posterior probabilities for this clade. The monophyly of the tribes Phanerotomini sensu van Achterberg (but including Adeliinae), Chelonini, and Odontosphaeropygini are highly supported in the concatenated analyses, while the single gene analyses and morphology alone show substantial differences. However, the tribes proposed by Zettel (1990), Phanerotomini sensu Zettel and Pseudophanerotomini (represented by Pseudophanerotoma and Furcidentia) are not recovered as monophyletic in all analyses.

Apart from the Bayesian morphology-only analysis, the Adeliinae are recovered within the Cheloninae in all analyses, with Adelius and Paradelius forming a clade with either Phanerotomella or Dentigaster, depending on the analysis. Most genera are recovered as monophyletic, with the exception of Ascogaster, Phanerotoma, and Pseudophanerotoma. Ascogaster is split in almost all analyses into two clades, a mostly 'North American' and a mostly 'Australian' clade, thus rendering the genus paraphyletic with respect to Austroascogaster, Leptodrepana, and Megascogaster. The only exception to this finding comes from the morphology-only analysis, where Ascogaster is monophyletic. In all analyses, Phanerotoma is rendered paraphyletic with respect to either Huseyinia, Phanaustrotoma, or both. The subgenera of Pseudophanerotoma included in the analyses, $P$. (Pseudophanerotoma) and P. (Furcidentia), are retrieved with strong support in all analyses as separate clades, but never together in a single monophyletic clade. The genus Chelonus s.l. is recovered as monophyletic with significant support in all analyses. However, neither of the major subgenera, C. (Chelonus) and C. (Microchelonus) (CH and MC, respectively, Fig. 1) form a monophyletic group. The only other subgenus, $M$. (Baculonus), represented by two species, is monophyletic. 


\subsection{Placements of fossils}

The topology generated in the non-clock analysis that included morphology and the fossils (Fig. 2) is the same, overall, as that obtained for the other analyses (see above), with almost all fossil taxa placed as expected. The fossil Chelonus and Ascogaster species are recovered with their extant counterparts. Diodontogaster is placed among the extant and fossil Ascogaster fossils, thus rendering the North American Ascogaster paraphyletic. However, Eobracon is placed within the Australian clade of Ascogaster, together with Austroascogaster and Megascogaster. The three fossil Phanerotoma species did not fall within the extant Phanerotoma clade, but rather are either placed basally within the Phanerotomini (P. extensa Brues, P. baltica Brues) or are recovered as closely related to Pseudophanerotoma (Pseudophanerotoma) and Pseudophanerotoma (Furcidentia) (P. menieri).

\subsection{Comparison of divergence-time estimates}

The divergence times estimated under three different approaches using a range of prior settings are summarised in Table 5. In the fixed-rate approach and under the default tree-age prior (gamma $(1,1)$ ), the median age of Cheloninae is estimated as $48 \mathrm{Ma}$ if the evolutionary rate is set to $2.3 \%$ for $C O 1$. Similarly, if the analyses are conducted without the $2.3 \%$ changes over time (default clockrate: 1 ), but translated to the clockrate of $2.3 \%$ after the analyses, a median age of $47 \mathrm{Ma}$ is inferred. However, if the tree-age prior is modified, the median age estimates change significantly. For instance, if the mean of the gamma-distributed prior on the tree age is modified from the default of 1 to 49 (gamma $(7,7)$ ), to reflect the posterior from the previous analyses, a median age of $93 \mathrm{Ma}$ is retrieved. The median age estimate for the subfamily becomes even older if the age of the oldest available fossil is used to constrain the root, as in the node-dating and total-evidence dating analyses (i.e., using an offsetexponential prior with minimum $=52 \mathrm{Ma}$ and a mean of $130 \mathrm{Ma}$ ): a median age of $139 \mathrm{Ma}$ is then inferred.

In the main node-dating analysis, a median age of $79 \mathrm{Ma}$ is inferred for the chelonines (Table 5). To examine the sensitivity to the node-age priors (Table 5), we also doubled the means of the calibration priors, while leaving their minima, which were based on fossil evidence, unchanged. If the prior for the mean age of either the root, the tribe Phanerotomini, 
or both is doubled, then the estimates are much older in all analyses (84 Ma, $100 \mathrm{Ma}$, or 141 Ma, respectively, Table 5).

The total-evidence dating analyses resulted in the highest estimates of the median age of the chelonines (Table 5). If the same minimum and mean age for the root is applied, as for the previous analyses, a median age of $170 \mathrm{Ma}$ is inferred. If the mean age of the root is doubled, then a median age of $206 \mathrm{Ma}$ is obtained. These results differ only slightly if either $1 / 3$ of the morphological characters are omitted (median age $=193 \mathrm{Ma})$ or $P$. menieri is excluded $(163$ Ma).

\section{Discussion}

\subsection{Implications for classification}

We here present the first total evidence phylogeny of Cheloninae which, although arguably limited by taxon sampling, nonetheless provides a relatively robust framework for re-evaluating the current classification of the subfamily.

Within Cheloninae, Zettel (1990) proposed four tribes (Table 1), while van Achterberg (1990) argued for just two, Chelonini and Phanerotomini; both authors treating Adeliinae as a separate subfamily. Our results support a classification recognising two tribes sensu van Achterberg, a monophyletic Chelonini and a monophyletic Phanerotomini, but the latter also including the adeliine genera without being attributed any higher rank.

Most chelonine genera are well diagnosed by a range of morphological characters (Zettel, 1990), and have also been retrieved as monophyletic in our analyses. However, there are a few noteworthy exceptions. The recovery of Ascogaster as paraphyletic in all analyses and particularly the recognition of two Ascogaster clades, a mostly 'North American' and a mostly 'Australian' clade, point to a possible biogeographic signal in the data, but this will require more detailed investigation. The latter is sister to Leptodrepana, Austroascogaster and Megascogaster, while the 'North American' clade is sister to all of them. The potentially paraphyletic nature of Ascogaster has been discussed previously based on morphological characteristics (Huddleston, 1984; Tang and Marsh, 1994; Shaw, 1997). Given the phylogenetic results here, two scenarios are possible; either the whole clade could be treated as Ascogaster s.l. and Austroascogaster, Leptodeprana, and Megascogaster synonymised under it, or the 'North American' clade could be treated as Ascogaster s.str. (in which the type species of the genus Ascogaster instabilis Wesmael belongs) and a new genus (which is 
morphologically virtually identical to Ascogaster) comprising the 'Australian' species be erected. The genera Leptodrepana, Megascogaster, and Austroascogaster would, thus, not be affected in the latter scenario. However, before any nomenclatural changes to Ascogaster are considered, a more detailed exploration of the characters defining each group would be required, along with a more comprehensive sampling of taxa representing each group.

The finding that Phanerotoma is paraphyletic with respect to Huseyinia and Phanaustrotoma in all analyses is limited by the fact that both species representing these latter two genera had $E F 1 \alpha$ sequences missing and incomplete $C O I$ and $28 S$ sequences. Thus, this relationship needs to be treated with caution until the data set is more complete and additional taxa can be added.

As the subgenera of Pseudophanerotoma (P. Pseudophanerotoma and P. Furcidentia) were distantly related in all analyses, we here propose that the subgenus Furcidentia be raised to generic rank (Furcidentia stat. rev.) with the following characters to distinguish the genus from Pseudophanerotoma as discussed by Zettel (1990): fore wing vein 1-SR+M emanating from the parastigma, clypeus without teeth, and wings infused with white a stripe under the parastigma.

The subgenus Microchelonus is not monophyletic, but is nested as multiple clades within Chelonus in all analyses, as predicted by van Achterberg and Polaszek (1996). Hence, the subgenus Microchelonus (syn. nov.) is synonymised with Chelonus as previously suggested by Muesebeck and Walkley (1951), and all species of Microchelonus transferred to Chelonus (see Appendix 4 for treatment of homonyms). Based on our results, formal synonymy with Chelonus is also applied to the included subgenera of Microchelonus (Baculonus syn. nov., Carinichelonus syn. nov.) and Chelonus (Scabrichelonus syn. nov.). Further, there is no evidence that the other previously recognised subgenera of Microchelonus (Areselonus, Megachelonus, Parachelonus, Rasnichelonus, and Stylochelonus), and of Chelonus (Cubochelonus) have any taxonomic utility although their synonymy should be confirmed by their inclusion in an expanded phylogenetic analysis.

\subsection{Divergence time estimates}

\subsubsection{Fixed clockrate}

For comparison with the other methods, we here included a number of fixed-rate dating analyses, which clearly exposed two shortcomings of this method. First, the divergence time 
estimates were highly sensitive to the prior on the tree age, with plausible modifications of the prior resulting in estimates that differed by a factor of two to three. This result is perhaps not too surprising given the large time-scale of at least tens of millions years that we are working with, and the reliance on an evolutionary-rate estimate for mitochondrial DNA. The deeper branches of the phylogeny are especially likely to have experienced a high degree of saturation in the $\mathrm{CO} 1$ sequences, and even though the nuclear genes help inform relative branch lengths (because we unlinked the evolutionary rates of the mitochondrial gene in our dataset) the tree-age prior has a major impact on determining the age estimates.

Second, the fixed rate for COI as suggested for insect taxa (Brower, 1994) might not be adequate for this group. Several studies have shown that there is a large variation among mitochondrial rates across various insect groups (Crozier et al., 1989; Johnson et al., 2003; Lin and Danforth, 2004; Thomas et al., 2006; Papadopoulou et al., 2010). Furthermore, the time scale employed when estimating evolutionary rates might have an impact on the outcome, with higher rates typically being estimated if more recent divergences are taken into account (Papadopoulou et al., 2010).

Importantly, this study adds to the accumulating evidence that fixed-rate dating analyses should be interpreted with caution. In the context of Bayesian inference, the impact of the prior on the tree age (and/or of the branch-length prior) has to be evaluated carefully, and sensitivity to deviations from the assumed evolutionary rate should be addressed. Over larger time-scales, saturation in mitochondrial genes further diminishes the power of this approach, even when modelled correctly. In the literature, fixed-rate approaches are currently mostly used to date divergences of less than a few million years; our study firmly supports the reservations against its use for estimating older nodes (Zheng et al., 2011).

\subsubsection{Node dating}

The precision of our node-dating approach was rather weak, as evident from the large 95\% credibility intervals (Fig. 3). This might be due to the fact that we had to ignore all but one fossil. However, P. menieri was somewhat problematic in that its morphology did not conform to the current definition of extant members of the genus (e.g., P. menieri has more than 23 antennomeres) and, hence, it could not be assigned to a specific node within the Phanerotomini and had to be placed at the root of the tribe. As P. menieri is also the oldest fossil in the dataset, it made all other fossils redundant for our analyses. Unfortunately, such a 
situation is rather common when searching the fossil record for specimens that could be used as reliable calibration points, and thus most fossil evidence never finds its way into nodedating analyses (Ronquist et al. 2012a). It has been shown that the results of a node-dating analysis generally improves with the number of fossils or calibration points (Sauquet et al., 2012). Therefore, reconsidering the placement of P. menieri and the other two Phanerotoma fossils, and assigning them to another more appropriate genus will probably allow for the other chelonine fossils to be used more effectively for this approach.

Our results show median ages between 79 to 140 Ma for the Cheloninae, depending on the prior settings on the calibration ages. The lowest median age of $79 \mathrm{Ma}$ is in concordance with the results of previous studies by Murphy et al. (2008) and Whitfield (2002). Murphy et al. (2008) estimated a mean age of $85 \mathrm{Ma} \pm 4.31$ for Cheloninae and 103.38 $\mathrm{Ma} \pm 4.41 \mathrm{Ma}$ for the microgastroid complex as a whole, using a fossil-calibrated penalised-likelihood approach. They included more than 42 fossils, 12 of which belonged to Cheloninae, and 48 sequenced specimens, again with 12 being chelonines. Whitfield (2002) estimated a mean age for the microgastroid complex of $73.7 \mathrm{Ma} \pm 10 \mathrm{Ma}$, also calibrated with fossils, albeit far fewer than the Murphy et al. study. However, the similarity of the median ages from our study with the results of these two previous studies does not necessarily mean that the estimates are accurate, but could rather be an artefact of using similar priors and the same node-dating approach.

As in the fixed-rate analyses, we observe a high sensitivity to the choice of prior distributions, in this case on the tree age and the age of the fossil-calibrated node. Once the mean of the calibration priors of the root and the Phanerotomini were modified, the divergence time of the chelonines changed drastically (Table 5). Such a pattern has been observed in previous studies (Inoue et al., 2010; Warnock et al., 2012; dos Reis et al., 2014), and is especially concerning because, although reasonable minima can often be inferred from the fossil record, there is no objective way of setting the mean of calibration distributions (Parham et al., 2012). The results of node-dating approaches thus strongly depend on the priors adopted and are only as good as the a-priori assumptions. In our case, we used means that corresponded to age estimates from the literature; even though this approach is used regularly in dating studies and creates the illusion of consistency with previous estimates, it should be rejected as circular. Alternative approaches that use the fossil record in a more informed way to derive age calibrations or estimates are promising in this context (Heath et 
al., 2014; Zhang et al., in press), but can only be applied to groups which fossilise comparatively well.

\subsubsection{Total-evidence dating}

The total-evidence dating approach was the least sensitive to the tree age prior, but estimates still vary from 163 Ma to $206 \mathrm{Ma}$ (Table 5). The $95 \%$ credibility interval was narrowest in this approach, but still very large. However, the median ages obtained for the chelonines are much older in the total-evidence approach compared to the other approaches, although the same root constraints were applied. It has been argued that the total-evidence dating approach is preferable from a philosophical point of view (Ronquist et al., 2012a), given that it requires fewer (arbitrary) assumptions regarding the calibration of the tree (i.e., in terms of placement of the fossils or setting of the priors). On the other hand, it makes one rather contentious assumption, which is that the data are at least compatible with a 'morphological clock' (Ronquist et al., 2012a; Beck and Lee, 2014). It remains to be shown how clock-like morphological data needs to be for total-evidence dating to work; in any case, our dataset seems to strongly reject this assumption. This is evident from the placement of the oldest fossil, $P$. menieri, which was not recovered as a basal taxon in the phylogeny, but rather is placed on a younger branch (Fig. 2). Furthermore, plotting the morphological branch lengths against molecular branch lengths (Fig. 4) reveals no correlation between the two. This could indicate that our dataset is not suitable for the total-evidence dating approach. Even though the impact of removing one third of the morphological data was rather small, the very low number of morphological characters (37) that we could score is certainly a large impediment. Due to the fact that most fossils have been lost and only the original descriptions of the species are available, we cannot extend the dataset without significantly increasing the amount of missing data.

\subsubsection{Estimating divergence time and age of Cheloninae}

The tendency for calculating older splits in calibrated trees with more recent analyses is not restricted to the microgastroid complex, but can be found widely among hymenopteran studies. For instance the most recent analyses of the whole order by Ronquist et al. (2012a) estimated an age of $309 \mathrm{Ma}$ for Hymenoptera and of about $260 \mathrm{Ma}$ for Apocrita (including Ichneumonoidea), based on a total-evidence dating approach. On the other hand, considerably 
younger ages were inferred with a node-dating approach in a recent study by Misof et al. (2014) who estimated the age of the order at around $240 \mathrm{Ma}$ and Ichneumonoidea about 140 Ma (but using unrealistically narrow node age priors, and none of the more ancient lineages of Hymenoptera). Other studies have estimated a mean age for the Hymenoptera based on node-dating (calibrating nodes of the tree based on fossils) at $220 \mathrm{Ma}$ (Wiegmann et al., 2009), 'modern Hymenoptera' at $200 \mathrm{Ma}$, and Ichneumonoidea to $150 \mathrm{Ma}$ (Grimaldi and Engel, (2005). The oldest described fossil of the order is Triassoxyela foveolata Rasnitsyn 1964 , with an age range of 235.0 to $221.5 \mathrm{Ma}$ (Rasnitsyn, 1964).

Indeed, there is a general tendency for more recent studies to estimate older ages for wasp lineages than previous attempts and this is likely due to a number of reasons (Thorne and Kishino, 2002; Ronquist et al., 2012a). Positive effects leading to older and possibly more accurate estimates might be attributed to recent studies being more comprehensive (more taxa and a greater number of markers; see Ronquist et al., 2012a), using more sophisticated analytical techniques, and including a greater array of fossils distributed more evenly across the tree (Smith et al., 2010). On the other hand, there are negative effects leading to a younger age, i.e., an incomplete fossil record, biases in the prior settings, model misspecification, or a combination of these factors (Thorne and Kishino, 2002).

Although our study infers that the subfamily Cheloninae may be considerably older than inferred by the simplistic approaches of a fixed clockrate and node-dating, the total-evidence estimate inferred here is implausible given that it is older than all current estimates for the superfamily Ichneumonoidea. Indeed, several studies came to the conclusion that totalevidence dating can overestimate divergence times (Ericson et al., 2014; Arcila et al., 2015). Only two other braconid subfamilies have been the subject of dating studies, both using a small number of fossils for the calibration and a node-dating penalised likelihood approach. These estimated a mean age of $50 \mathrm{Ma}$ for Rogadinae (36-51 Ma) and 55-59 Ma for Doryctinae (Zaldivar-Riverón et al., 2008a; Zaldivar-Riverón et al., 2008b); both are likely to be significant under-estimates. The total-evidence dating approach is still rather young and more experience with this method is needed to confirm a possible tendency of inferring ages that are too old and potential causes of this, such as a taxonomically biased sampling of morphological characters or an inadequate tree prior (Beck and Lee, 2014; Zhang et al., 2016). 


\section{Conclusion}

This study represents the most comprehensive phylogenetic estimate of relationships for chelonine wasps. The results confirm the presence of two well-supported tribes and the monophyly of most genera. Unfortunately, some rare genera (Phanerotomoides, Sculptomyriola, Sinadelius, Siniphanerotomella, and Wushenia) could not be included, because specimens were unavailable or the quality or the quantity of their DNA was inadequate. Including more taxa of the rarer genera and a greater geographic spread for the larger genera will improve on our phylogenetic results by providing more robust information on their sister relationships.

Three divergence time estimates were employed, including a fixed clockrate, a nodedating, and total-evidence dating in which molecular and morphological data were combined from extant and fossil taxa. The results show a large range of median ages for chelonine wasps, depending on the analysis and the prior being used. It is likely that none of the three divergence time approaches inferred a realistic age for the chelonines. The fixed clockrate and the node-dating approaches are likely to be flawed and to underestimate ages, while our current dataset for chelonines is not suitable for the total-evidence approach. With a greater array of morphological characters and more fossil taxa, the total-evidence approach has the potential to yield realistic age estimates of the group, but only if the morphological data is sufficiently clock-like. As all three approaches have specific limitations (varying rates for each taxon in fixed clockrate, sensitivity of priors in node-dating, morphological clock requirement for total-evidence), we suggest that the interpretation of all published dating studies be carefully scrutinised. This is crucial because the majority of current studies that estimate divergence time are based on the node-dating approach (Särkinen et al., 2013; Brady et al., 2014). Despite the group being relatively well-represented in the fossil record, our comparison of approaches clearly demonstrates that dating the chelonine tree is currently not possible with reasonable confidence. Divergence dates are repeatedly proposed for groups on an even weaker basis and without careful examination of the sensitivity of the age estimates to the calibration priors.

\section{Acknowledgements}

We thank the following people for material and hospitality during visits to various institutions: Yves Braet (Université de Liège) for specimens from French Guiana and the Société Entomologique Antilles Guyane (S.E.A.G.); Mike Sharkey (University of Kentucky) 
and his collaborators (Survey in Thailand was supported by National Science Foundation (NSF) grant: DEB-0542864, surveys in Central America were supported by NSF grant DEB0640015 (Project LLAMA), surveys in Madagascar were supported by NSF grant DEB0072713 to BL Fisher and CE Griswold and DEB-0344731 to BL Fisher and PS Ward, as well as by the Schlinger Foundation to Mike Irwin and Ev Schlinger, with Harinhala Rinha, who carried out the fieldwork and supervised the processing in Antananarivo; Simon van Noort (Iziko South African Museum); Jim Whitfield (University of Illinois); Julia Stigenberg (Naturhistoriska Riksmuseet, Sweden); Donald Quicke and Gavin Broad (Natural History Museum, UK); Kees van Achterberg (Naturalis Biodiversity Centre, Netherlands); Bob Kula (National Museum of Natural History, USA); Jenő Papp and Gellért Puskás (Magyar Természettudományi Múzeum, Hungary); Gary Taylor (University of Adelaide). We also thank Nick Murphy for the outgroup sequences, Simon Tierney for his computing knowledge, and Steve Cooper and John Jennings for their comments on early drafts of the manuscript. This project was supported financially by the Australian Biology Resources Study (grants ATC212-13 and TTC211-06), Lirabenda Endowment Fund, Sir Mark Mitchell Research Grant, a University of Adelaide PhD scholarship (Adelaide Scholarship International), to RNK, ABRS grant (RF214-16) to ADA, and a Swiss National Science Foundation grant (PA00P3_145377/1) to SK. 


\section{Bibliography}

Achterberg C. van, 1976. A preliminary key to the subfamilies of the Braconidae (Hymenoptera). Tijdschr Entomol, 119, 33-78.

Achterberg C. van, 1984. Essay on the phylogeny of Braconidae (Hymenoptera: Ichneumonoidea). Ent Tidskr, 105, 41-58.

Achterberg C. van, 1990. Revision of the western Palaearctic Phanerotomini (Hymenoptera: Braconidae). Zool Verh (Leiden), 255, 1-106.

Achterberg C. van, 1993. Illustrated key to the subfamilies of the Braconidae (Hymenoptera: Ichneumoidea). Zool Verh (Leiden), 283, 1-189.

Achterberg C. van \& Polaszek A., 1996. The parasites of cereal stem borers (Lepidoptera: Cossidae, Crambidae, Noctuidae, Pyralidae) in Africa, belonging to the family Braconidae (Hymenoptera: Ichneumonoidea). Zool Verh (Leiden), 304, 1-123.

Arcila D., Pyron R.A., Tyler J.C., Orti G., \& Betancur-R R., 2015. An evaluation of fossil tip-dating versus node-age calibrations in tetraodontiformes fishes (Teleostei: Percomorphaceae). Mol. Phylogenet. Evol., 82, 131-145.

Baker C.F., 1926. Braconidae-Cheloninae of the Philippines, Malaya, and Australia. 1. Chelonini (except Chelonus). Philipp J Sci, 31, 451-489.

Beck R.M.D. \& Lee M.S.Y., 2014. Ancient dates or accelerated rates? Morphological clocks and the antiquity of placental mammals. Proc R Soc B, 281, 20141278. dx.doi.org/10.1098/rspb.2014.1278

Belokobylskij S.A., Nel A., Waller A., \& De Plöeg G., 2010. New fossil non-cyclostome braconid wasps from the lowermost Eocene amber of Paris Basin. Acta Palaeontol Pol, 55, 519-527. doi:10.4202/app.2009.1114

Belshaw R., Dowton M., Quicke D., \& Austin A., 2000. Estimating ancestral geographic distributions: a Gondwanan origin for aphid parasitoids? Proc. R. Soc. London B, 267, 491-496.

Belshaw R. \& Quicke D.L.J., 1997. A molecular phylogeny of the Aphidiinae (Hymenoptera: Braconidae). Mol Phylogenet Evol, 7, 281-293. doi:10.1006/mpev.1996.0400

Belshaw R. \& Quicke D.L.J., 2002. Robustness of ancestral state estimates: evolution of life history strategy in ichneumonoid parasitoids. Syst. Biol., 51, 450-477.

Brady S.G., Fisher B.L., Schultz T.R., \& Ward P.S., 2014. The rise of army ant and their relatives: diversification of specialized predatory doryline ants. BMC Evol Biol, 14. 
Braet Y., 1999. Description of new Braconidae (Hymenoptera) from Papua New Guinea. Belg J Zool, 1, 3-20.

Brajkovic M., Nikolic Z., Curcic S.B., Zivic I., \& Stojanovic D., 2010. Morphological changes of the ovipositor in species of Cheloninae (Hymenoptera: Braconidae) in the course of adaptation to egg-larval parasitism. Arch Biol Sci, 62, 469-477. doi:10.2298/abs1002469b

Brower A.V.Z., 1994. Rapid morphological radiation and convergence among races of the butterfly Heliconius erato inferred from patterns of mitochondrial DNA Evolution. Proc Natl Acad Sci USA, 91, 6491-6495.

Brues C.T., 1910. The parasitic Hymenoptera of the Tertiary of Florissant, Colorado. Bull Mus Comp Zool, 54, 1-126.

Brues C.T. 1933 The Parasitic Hymenoptera of the Baltic amber, part 1 Bernstein Forschungen (Vol. 3, pp. 4-178). Berlin: Walter de Gruyter \& Co.

Cameron P., 1905. New Hymenoptera, mostly from Nicaragua. Inv Pac, 1, 46-69.

Chandra S.B.C., Vik J.L., \& V K., 2006. Comparative insect mitochondrial genomes: Differences despite conserved genome synteny. Afr J Biotechnol, 5, 1308-1318.

Chen J. \& Ji Q. 2003. Systematic studies on Cheloninae of China (Hymenoptera: Braconidae)(in Chinese with English summary). Fuchow, China: Fujian Scientific Publishers.

Clausen C.P., 1956. The egg-larval host relationship among the parasitic Hymenoptera. Bol Lab Zoo Gen Agr Portici, 33, 119-133.

Cockerell T.D.A., 1920. Eocene insects from the Rocky mountains. Proc of the US Nat Mus, 57, 233-260. doi:10.5479/si.00963801.57-2313.233

Crozier R.H., Crozier Y.C., \& Mackinlay A.G., 1989. The CO-I and CO-II region of honybee mitochondrial DNA: evidence for variations in insect mitochondrial evolutionary rates. Mol Biol Evol, 6, 399-411.

Dallwitz M., Paine T.A., \& Zurcher E., 1999. User's guide to the DELTA Editor. http://deltaintkey.com.

dos Reis M., Donoghue P.C.J., \& Yang Z., 2014. Neither phylogenomic nor palaeontological data support a Palaeogene origin of placental mammals. Biol Lett, 10, 20121003. doi: $10.1098 / \mathrm{rsbl} .2013 .1003$

Dowton M., Belshaw R., Austin A.D., \& Quicke D.L.J., 2002. Simultaneous molecular and morphological analysis of braconid relationship (Insecta: Hymenoptera: Braconidae) 
indicates independent mt-tRNA gene inversions within a single wasp family. J Mol Evol, 54, 210-226. doi:10.1007/s00239-001-0003-3

Drummond A., Ashton B., Buxton S., Cheung M., Cooper A., Duran C., Field M., Heled J., Kearse M., Markowitz S., Moir R., Stones-Havas S., Sturrock S., Thierer T., \& Wilson A., 2011. Geneious v5.4 Available from http://www.geneious.com/. doi:10.1093/bioinformatics/bts199

Dudarenko G.P., 1974. Formation of the abdominal carapace in braconids (Hymenoptera, Braconidae) and some aspects of the classification of the family. Ent Obozr, 53, 14129.

Emry R.J. 1973. Stratigraphy and Preliminary Biostratigraphy of the Flagstaff Rim Area, Natrona County, Wyoming (Vol. 18). Washington,D.C.: Smithsonian Institution Press.

Ericson P.G.P., Klopfstein S., Irestedt M., Nguyen J.M.T., \& Nylander J.A.A., 2014. Dating the diversification of the major lineages of Passeriformes (Aves). BMC Evol Biol, 14. Fahringer J. 1934 Opuscula braconologica. Band 3 Palaearktischen Region (Vol. Lieferung 58, pp. 321-594). Wien: Fritz Wagner.

Folmer O., Black M., Hoeh W., Lutz R., \& Vrijenhoek R., 1994. DNA primers for amplification of mitochondrial cytochrome c oxidase subunit I from diverse metazoan invertebrates. Mol Mar Biol Biotechnol, 3, 294-297.

Georges A., Birrell J., Saint K.M., McCord W.P., \& Donnellan S.C., 1998. A phylogeny for side-necked turtles (Chelonia: Pleurodira) based on mitochondrial and nuclear gene sequence variation. Biol J Linn Soc, 67, 213-246. doi:10.1111/j.10958312.1999.tb01862.x

Grimaldi D. \& Engel M.S. 2005. Evolution of the Insects: Cambridge University Press. He J., 1994. Two new species of Chelonus from Shaanxi province (Hymenoptera: Braconidae) (in Chinese with English summary). J Shaanxi Normal Uni Nat Sci, 22, 56-58.

He J.p., 2003. Two new species and a new record of genus Chelonus (Hymenoptera: Braconidae) (in Chinese with English summary). J Shaanxi Normal Uni Nat Sci, 31, 102-106.

Heath T.A., Huelsenbeck J.P., \& Stadler T., 2014. The fossilised birth-death process for coherent calibration of divergence-time estimates. PNASE2957-E2966. 10.1073/pnas.1319091111 
Huddleston T., 1984. The palaearctic species of Ascogaster (Hymenoptera: Braconidae). Bull Br Mus nat Hist (Ent), 49, 341-392.

Huddleston T. \& Walker A.K., 1994. A revision of Chelonus scrobiculatus species-group of Cheloninae (Insecta: Hymenoptera: Braconidae). Ann Naturhist Mus Wien, 96, 153 168.

Inoue J., Donoghue P.C.J., \& Yang Z., 2010. The impact of the representation of fossil calibration on bayesian estimates of species divergence times. Syst Biol, 59, 74-89. doi:10.1093/sysbio/syp078

Jackson C.G., Delph J.S., \& Neemann E.G., 1978. Development, longevity and fecundity of Chelonus blackburni (Hym: Braconidae) as a parasite of Pectinophora gossypiella (Lepidoptera: Gelchiidae). Entomophaga, 23, 35-42. doi:10.1007/bf02371989

Johnson K.P., Cruickshank R.H., Adams R.J., Smith V.S., Page R.D.M., \& Clayton D.H., 2003. Dramatically elevated rate of mitochondrial substitution in lice (Insecta: Phthiraptera). Mol Phylogenet Evol, 26, 231-242. doi:10.1016/S1055-7903(02)003421

Kittel R.N. \& Austin A.D., 2014. Synopsis of Australian chelonine wasps (Hymenoptera: Braconidae: Cheloninae) with description of two new genera. Austral Ent, 53, 183202. doi:10.1111/aen. 12070

Kittel R.N. \& Austin A.D., 2015. New species of Australian arid zone chelonine wasps from the genera Phanerotoma and Ascogaster (Hymenoptera: Braconidae) informed by the 'Bush Blitz' surveys of national reserves. J Nat Hist. doi:10.1080/00222933.2015.1074747

Klopfstein S. \& Ronquist F., 2013. Convergent intron gains in hymenopteran elongation factor-1 $\alpha$. Mol Biol Evol, 67, 266-276. doi:10.1016/j.ympev.2013.01.015

Koressaar T. \& Remm M., 2007. Enhancements and modifications of primer design program Primer3. Bioinformatics, 23, 1289-1291. doi:10.1093/bioinformatics/btm091

Lanfear R., Calcott B., Ho S.Y.W., \& Guindon S., 2012. PartitionFinder: Combined Selection of Patitioning Schemes and Substitution Models for Phylogenetic Analyses. Mol Biol Evol, 29, 1695-1701. doi:10.1093/molbev/mss020

Lin C.-P. \& Danforth B.N., 2004. How do insects nuclear and mitochondrial gene substitution patterns differ? Inseights from Bayesian analyses of combined datasets. Mol Phylogenet Evol, 30, 686-702. doi:10.1016/S1055-7903(03)00241-0 
Lozan A. \& Tobias V., 2006. Species of the genus Microchelonus Szepligeti, 1908 with very small apical metasomal aperture in males (Hymenoptera: Braconidae: Cheloninae). Ann Zool (Wars), 56, 327-334.

Mardulyn P. \& Whitfield J.B., 1999. Phylogenetic signal in the CO1, 16S, and 28S genes for interferring relationships among genera of Microgastrinae (Hymenopera:

Braconidae): evidence of a high diversification rate in this group of parasitoids. Mol Phylogenet Evol, 12, 282-294. doi:10.1006/mpev.1999.0618

McComb C.W., 1968. A revision of the Chelonus subgenus Microchelonus in North America north of Mexico (Hymenoptera: Braconidae). Maryland AES Bull A- Series, A-149, $1-148$

McIntosh W.C., Geissman J.W., Chapin C.E., Kunk M.J., \& Henry4 C.D., 1992. Calibration of the Latest Eocene-Oligocene geomagnetic Polarity Time Scale Using 40Ar/39Ar Dated Ignimbrites. Geology, 20, 459-463. doi:10.1130/00917613(1992)020<0459:cotleo>2.3.co;2

McKellar R.C. \& Wolfe A.P. 2010 Canadian Amber. In D Penny (Ed.), Biodiversity of the Fossils in Amber from Major World Deposits (pp. 96-113): Siri Scientific Press.

Miller M.A., Pfeiffer W., \& Schwartz T. 2010. Creating the CIPRES Science Gateway for inference of large phylogenetic trees. Paper presented at the Proceedings of the Gateway Computing Environments Workshop (GCE).

Misof B.Liu S.Meusemann K.Peters R.S.Donath A.Mayer C.Frandsen P.B.Ware J.Flouri T.Beutel R.G.Niehuis O.Petersen M.Izquierdo-Carrasco F.Wappler T.Rust J.Aberer A.J.Aspöck U.Aspöck H.Bartel D.Blanke A.Berger S.Böhm A.Buckley T.R.Calcott B.Chen J.Friedrich F.Fukui M.Fujita M.Greve C.Grobe P.Gu S.Huang Y.Jermiin L.S.Kawahara A.Y.Krogmann L.Kubiak M.Lanfear R.Letsch H.Li Y.Li Z.Li J.Lu H.Machida R.Mashimo Y.Kapli P.McKenna D.D.Meng G.Nakagaki Y.NavarreteHeredia J.L.Ott M.Ou Y.Pass G.Podsiadlowski L.Pohl H.von Reumont B.M.Schütte K.Sekiya K.Shimizu S.Slipinski A.Stamatakis A.Song W.Su X.Szucsich N.U.Tan M.Tan X.Tang M.Tang J.Timelthaler G.Tomizuka S.Trautwein M.Tong X.Uchifune T.Walzl M.G.Wiegmann B.M.Wilbrandt J.Wipfler B.Wong T.K.Wu Q.Wu G.Xie Y.Yang S.Yang Q.Yeates D.K.Yoshizawa K.Zhang Q.Zhang R.Zhang W.Zhang Y.Zhao J.Zhou C.Zhou L.Ziesmann T.Zou S.Li Y.Xu X.Zhang Y.Yang H.Wang J.Wang J.Kjer K.M. \& Zhou X., 2014. Phylogenomics resolves the timing and pattern of insect evolution. Science, 346, 763-767. DOI: 10.1126/science.1257570 
Muesebeck C.F.W. \& Walkley L. 1951 Braconidae. In CFW Muesebeck, KV Krombein \& HK Townes (Eds.), Hymenoptera of America North of Mexico - Synopsis Catalog (Vol. Agriculture Monograph No 2, pp. 90-184). Washington, D.C.: United States Department of Agriculture.

Murphy N., Banks J.C., Whitfield J.B., \& Austin A.D., 2008. Phylogeny of the parasitic microgastroid subfamilies (Hymenoptera: Braconidae) based on sequence data from seven genes, with an improved time estimate of the origin of the lineage. Mol Phylogenet Evol, 47, 378-395. doi:10.1016/j.ympev.2008.01.022

Nel A., de Ploëg G., Dejax J., Dutheil D., de Franceschi D., Gheerbrant E., Godinot M., Hervet S., Menier J.J., Augé M., Bignot G., Cavagnetto C., Duffaud S., Gaudant J., Hua S., Jossang A., de Lapparent de Broin F., Pozzi J.P., Paicheler J.C., Bouchet F., \& Rage J.C., 1999. Un gisement sparnacien exceptionnel à plantes, arthropodes et vertébrés (Éocène basal, MP7): Le Quesnoy (Oise, France). C R Acad Sci Sci Terre Planetes, 329, 65-72. doi:10.1016/s1251-8050(99)80229-8

Papadopoulou A., Anastasiou I., \& Vogler A., 2010. Revisiting the Insect Mitochondrial Molecular Clock: The Mid-Aegean Trench Calibration. Mol Biol Evol, 27, 16591972. doi:10.1093/molbev/msq051

Papp J., 1971. Results of the zoological explorations of Dr. Z. Kaszab in Mongolia. Hymenoptera: Braconidae II. Acta Zool Hung, 17, 51-90.

Papp J., 1992. Braconidae (Hymenoptera) from Mongolia, Acta Zool Hung, 12. 38, 293-312. Papp J., 1995. Revision of Wesmael's Chelonus species (Hymenoptera Braconidae Cheloninae). Entomologie, 65, 115-134.

Parham J.F., Donoghue P.C.J., Bell C.J., Calway T.D., Head J.J., Holroyd P.A.I., J. G., Irmis R.B., Joyce W.G., Ksepka D.T., Patane J.S.L., Smith N.D., Tarver J.E., Tuinen M.v., Yang Z., Angielczyk K.D., Greenwood J., Hipsley C.A., Jacobs L., Makovicky P.J., Mueller J., Smith K.T., Theodor J.M., Warnock R.C.M., \& Benton M.J., 2012. Best Practices for Justifying Fossil Calibrations. Syst Biol, 61, 346-359.

Posada D. \& Buckley T.R., 2004. Model selection and model averaging in phylogenetics: advantages of akaike information criterion and bayesian approaches over likelihood ratio tests. Syst Biol, 53, 793-808.

Quicke D.L.J. 2015. The Braconid and Ichneumonid Parasitoid Wasps: Biology, Systematics, Evolution and Ecology: Wiley Blackwell.

Quicke D.L.J. \& Achterberg C. van, 1990. Phylogeny of the subfamilies of the family Braconidae (Hymenoptera: Ichneumonoidea). Zool Verh (Leiden), 258, 1-95. 
Rao S.N. \& Chalikwar M.R., 1971. Studies on parasitic Hymenoptera (Braconidae) from Marathwada: III. Three new species of Chelonus Panzer. Oriental Insects, 5, 469-476. Rasnitsyn A.P., 1964. Novye Triasovye pereponchatokrylye sredney Azii. 1964, 88-96. Ritzkowski S. 1997 K-Ar Altersbestimmungen der bernsteinführenden Sedimente des Samlandes (Palaögen, Bezirk Kaliningrad). In M Ganzelewski, TH Rehren \& R Slotta (Eds.), Metalla, Sonderheft 66 zum Symposium Neue Erkenntnisse zum Bernstein (pp. 19-24). Bochum, Germany: Deutsches Bergbau Museum.

Ronquist F. \& Huelsenbeck J.P., 2003. MrBayes 3: Bayesian phylogenetic inference under mixed models. Bioinformatics, 19, 1572-1574. doi:10.1093/bioinformatics/btg180 Ronquist F., Klopfstein S., Vilhelmsen L., Schulmeister S., Murray D., \& Rasnitsyn A.P., 2012a. A total-evidence approach to dating with fossils, applied to the early radition of the Hymenoptera. Syst Biol, 61, 973-999.

Ronquist F., Teslenko M., van der Mark P., Ayres D.L., Darling A., Höhna S., Larget B., Liu L., Suchard M.A., \& Huelsenbeck J.P., 2012b. MrBayes 3.2: efficient Bayesian phylogenetic inference and model choice across a large model space. Syst Biol, 61, 539-542. doi:10.1093/sysbio/sys029

Ruberson J.R. \& Whitfield J.B., 1996. Facultative egg-larval parasitism of the beet armyworm, Spodoptera exigua (Lepidoptera: Noctuidae) by Cotesia marginiventris (Hymenoptera: Braconidae). Florida Ent, 79, 296-302.

Särkinen T., Bohs L., Olmstead R.G., \& Knapp S., 2013. A phylogenetic framework for evolutionary study of the nightshades (Solanaceae): a dated 1000-tip tree. BMC Evol Biol, 13.

Sauquet H., Ho S.Y.W., Gandolfo M.A., Jordan G.J., Wilf P., Cantrill D.J., Bayly M.J., Bromham L., Brown G.K., Carpenter R.J., Lee D.M., Murphy D.J., Sniderman J.M.K., \& Udivicic F., 2012. Testing the impact of calibration on molecular divergence times using a fossil-rich group: the case of Nothofagus (Fagales). Syst Biol, 61, 289-313. DOI:10.1093/sysbio/syr116

Shaw S.R., 1983. A taxonomic study of Nearctic Ascogaster and a description of a new genus Leptodrepana (Hymenoptera: Braconidae). Entomography, 2, 1-54.

Shaw S.R. 1997 Subfamily Cheloninae. In RA Wharton, PM Marsh \& MJ Sharkey (Eds.), Identification Manual of the New World Genera of the Family Braconidae Hymenoptera vol. 1 (pp. 192-201). Washington, DC International Society of Hymenopterists Special Publication.

Shenefelt R.D. (Ed.). 1973. Braconidae 6 Cheloninae. Gravenhage, Netherlands: W. Junk. 
Shi M., Chen X.X., \& Achterberg C. van, 2005. Phylogenetic relationships among the Braconidae (Hymenoptera: Ichneumonoidea) inferred from partial 16S rDNA, 28S rDNA D2, 18S rDNA gene sequences and morphological characters. Mol Phylogenet Evol, 37, 104-116. doi:10.1016/j.ympev.2005.03.035

Shi M., Zhang H.Y., \& Chen X.X., unpublished. Phylogenetic relationships among genus Chelonus (Braconidae: Cheloninae) based on molecular data of $16 \mathrm{~S}$ and $18 \mathrm{~S}$ genes and morphological data.

Simmons M.P., Zhang L.-B., Webb C.T., \& Reeves A., 2006. How Can Third Codon Positions Outperform First and Second Codon Positions in Phylogenetic Inference? An Empirical Example from the Seed Plants. Syst Biol, 55, 245-258.

Simon C., Frati F., Beckenbach A., Crespi B., Liu H., \& Flook P., 1994. Evolution, weighting, and phylogenetic utility of mitochondrial gene sequences and a compilation of conserved polymerase chain reaction primers. Ann Entomol Soc Am, 87, 651-701.

Smith S.A., Beaulieu J.M., \& Donoghue M.J., 2010. An uncorrelated relaxed-clock analysis suggests an earlier origin of flowring plants. PNAS, 107, 5897-5902. doi/10.1073/pnas.1001225107

Stamatakis A., 2006. RAxML-VI-HPC: Maximum Likelihood-based Phylogenetic Analyses with Thousands of Taxa and Mixed Models. Bioinformatics, 22, 2688-2690. doi:10.1093/bioinformatics/btl446

Swofford D.L. 2003 PAUP*. Phylogenetic Analysis Using Parsimony (*and Other Methods). Version 4. doi:doi:10.1017/cbo9780511819049.010

Szépligeti G., 1900. Braconiden aus Neu-Guinea in der Sammlung des ungarischen National Museums. Termés Fü, 23, 49-65.

Szépligeti G., 1989. Beiträge zur Kenntniss der Chelonus-Arten. Termés Fü, 21, 207-218 (Hungarian), 218-231 (German).

Tang Y. \& Marsh P.M., 1994. A taxonomic study of the genus Ascogaster in China (Hymenoptera: Braconidae: Cheloninae). J Hymenop Res, 3, 279-302.

Thomas J.A., Welch J.J., \& Woolfit L.B., 2006. There is no universal molecular clock for invertebrates, but rate variation does not scale with body size. PNAS, 103, 7366-7371.

Thompson J.D., Higgins D.G., \& Gibson T.J., 1994. CLUSTAL W: Improving the sensitivity of progressive multiple sequence alignment through sequence weighting, positionspecific gap penalties and weight matrix choice. Nucleic Acids Res, 22, 4673-4680. doi:10.1093/nar/22.22.4673 
Thomson C.G., 1874. XXIV. Öfversigt af Sveriges Sigalpher. Opus Entomol, 6, 553-588.

Thorne J.L. \& Kishino H., 2002. Divergence time and evolution rate estimation with multilocus data. Syst Biol, 51, 689-702. doi:10.1080/10635150290102456

Tobias V.I., 1964. New species and genus of Braconids (Hymenoptera, Braconidae) from Kazakhstan. Trudy Zool Inst, 34, 177-234.

Tobias V.I., 1972. Contributions to the knowledge of the subgenus Chelonus s. str. of the USSR and near-by territories (in Russian). Trudy Vseso Entom Obsh, 55, 284-299.

Tobias V.I., 1974. Contribution to the knowledge of the Braconids (Hymenoptera, Braconidae) (in Russian). Nase Mong, 4, 261-274.

Tobias V.I. 1986a Cheloninae. In GS Medvedev (Ed.), Opredelitel Nasekomych Evrospeiskoi Tsasti SSSR 3, Peredpontdatokrylye 4. Opr. Faune SSSR (pp. 293-335).

Tobias V.I. 1986b New species of Microchelonus Szépl. (Hymenoptera, Braconidae) from the Soviet Far East (in Russian). In PA Ler, SA Belokobylskij \& NA Storozheva (Eds.), Pereponchatokrylye Vostochnoy Sibiri i Dal'nego Vostoka (pp. 152 pp). Vladivostok.

Tobias V.I., 1989. Wasps of the genus Microchelonus (Hymenoptera, Braconidae) of Mongolia (in Russian). Nase Mong, 10, 413-505.

Tobias V.I., 1994a. Description of two species (one new species) of the genus Microchelonus from Austria (Insecta: Hymenoptera: Braconidae). Ann Naturhist Mus Wien, 96B, 169-172.

Tobias V.I. 1994b On braconid parasitic wasp of the genus Microchelonus Szepl. (Hymenoptera, Braconidae) of the Baikal region. In AG Kotenko (Ed.), Hymenopteran insects of Siberia and Far East: memoirs of the Daursky Nature Reserve, no. 3 (pp. 129-139). Kiev: Institut zoologii NAN Ukrainy.

Tobias V.I., 1996. A key to Mongolian species of braconid wasps of the genus Microchelonus Szepl. (Hymenoptera, Braconidae) based on male characters (with description of new species). Entomol Obo, 75, 380-407; Ento Rev, 376, 719-742.

Tobias V.I., 2001. Species of the genus Microchelonus Szépl. (Hymenoptera, Braconidae) with yellow abdominal spots and pale coloration of the body from the western Palaearctic region. Entomol Obo, 80, 137-179; Ento Rev, 180, 134-165.

Tobias V.I., 2008. Palaearctic species of the Microchelonus retusus group (Hymenoptera, Braconidae, Cheloninae). Entomol Obo, 87, 880-909; Ento Rev, 888, 1171-1191. 
Tobias V.I., 2011. Genus Chelonus Jurine (Hymenoptera, Braconidae, Cheloninae) in the fauna of Russia and adjacent territories. Ch. olgae Kok. species group (in Russian). Entomol Obo, 90, 416-438; Ento Rev, 491, 1011-1030.

Warnock R.C.M., Yang Z., \& Donoghue P.C.J., 2012. Exploring uncertainty in the calibration of the molecular clock. Biol Lett, 8, 156-159. doi:10.1098/rsbl.2011.0710

Wharton R.A., Shaw S.R., Sharkey M.J., Wahl D.B., Woolley J.B., Whitfield J.B., Marsh P.M., \& Johnson W., 1992. Phylogeny of the subfamilies of the family Braconidae (Hymenoptera: Ichneumonoidea): a reassessment. Cladistics, 8, 199-235. doi:10.1111/j.1096-0031.1992.tb00068.x

Whitfield J.B., 2002. Estimating the age of the polydnavirus/braconid wasp symbiosis. Proc Natl Acad Sci USA, 99, 7508-7513. doi:10.1073/pnas.112067199

Wiegmann B.M., Trautwein M.D., Kim J.-W., Cassell B., VBertone M.A., Winterton S.L., \& Yeates D.K., 2009. Single-copy nuclear genes resolve the phylogeny of the holometabolous insects. BMC Biol, 7. doi:10.1186/1741-7007-7-34

Yu D.S., Achterberg C. van, \& Horstmann K. (Eds.). 2012 Database on flash-drive. www.taxapad.com. Ottawa, Ontario, Canada.

Zaldivar-Riverón A., Belokobylskij S.A., León-Regagnon V., Briceño-G R., \& Quicke D.L.J., 2008a. Molecular phylogeny and historical biogeography of the cosmopolitan parasitic wasp subfamily Doryctinae (Hymenoptera:Braconidae). Inv Syst, 22, 345363. doi:10.1071/is07028

Zaldivar-Riverón A., Shaw M.R., Sáez A., Mori M., Belokobylskij S.A., Shaw S.R., \& Quicke D.L.J., 2008b. Evolution of the parasitic wasp subfamily Rogadinae (Braconidae): phylogeny and evolution of lepidopteran host ranges and mummy characteristics. BMC Evol Biol, 8. doi:10.1186/1471-2148-8-329

Zettel H., 1990. Eine Revision der Gattungen der Cheloninae (Hymenoptera, Braconidae) mit Beschreibungen neuer Gattungen und Arten. Ann Naturhist Mus Wien, 91, 147-196.

Zettel H., 1992. Revision der Phanerotoma - Arten Nordamerikas (Hymenoptera: Braconidae, Cheloninae). Linz Biol Beitr, 24, 275-330.

Zhang C., Stadler T., Klopfstein S., Heath T.A., \& Ronquist F., 2016. Total-evidence dating under the fossilized birth-death process. Syst Biol, 65, 228-249. doi:10.1093/sysbio/syv080.

Zhang H.Y., Shi M., He J.H., \& Chen X.X., 2008. New species and records of the subgenus Microchelonus Szépligeti (Braconidae: Cheloninae) from China. Biologia, 63, $107-$ 112. doi:10.2478/s11756-008-0001-7 
Zheng Y., Peng R., Kuro-o M., \& Zeng X., 2011. Exploring patterns and extent of bias in estimating divergence time from mitochondrial DNA sequence data in a particular lineage: a case study of salamanders (Order Caudata). Mol Biol Evol, 28, 2521-2535. doi:10.1093/molbev/msr072 


\section{Figures and Table}

Table 1. Genera of chelonine wasps and their corresponding tribes according to Zettel (1990) and the former separate subfamily Adeliinae, including the distribution of each genus, number of described species and number of species used in this study. Indented generic names are those variously treated as synonyms or subgenera by various authors.

\begin{tabular}{|c|c|c|c|c|}
\hline Tribe & $\begin{array}{r}\text { Taxon } \\
\end{array}$ & $\begin{array}{l}\text { scribed } \\
\text { spp }\end{array}$ & $\begin{array}{l}\text { Taxa } \\
\text { incl. }\end{array}$ & Distribution \\
\hline \multirow{16}{*}{$\begin{array}{l}\text { Chelonini Förster } \\
1826\end{array}$} & Ascogaster Wesmael 1835 & 154 & 14 & Worldwide \\
\hline & Leptodrepana Shaw 1983 & & 6 & \\
\hline & Chelonus Jurine 1801 & 905 & 10 & Worldwide \\
\hline & Microchelonus Szépligeti 1908 & & 12 & \\
\hline & Areselonus Braet 1999 & & - & \\
\hline & $\begin{array}{l}\text { Baculonus Braet \& van Achterberg } \\
2001\end{array}$ & & 2 & \\
\hline & Carinichelonus Tobias 2000 & & 1 & \\
\hline & Cubochelonus Baker 1926 & & - & \\
\hline & Megachelonus Baker 1926 & & - & \\
\hline & Parachelonus Tobias 1995 & & - & \\
\hline & $\begin{array}{l}\text { Scabrichelonus He, Chen \& van } \\
\text { Achterberg } 1997\end{array}$ & & 1 & \\
\hline & Rasnichelonus Tobias 2011 & & - & \\
\hline & Diodontogaster Brues 1933 & 1 & - & Fossil \\
\hline & Eobracon Cockerell 1921 & 1 & - & Fossil \\
\hline & Megascogaster Baker 1926 & 1 & 1 & Oriental \\
\hline & Austroascogaster Kittel \& Austin 2014 & 4 & 1 & Australasian \\
\hline \multirow{5}{*}{$\begin{array}{l}\text { Odonto- } \\
\text { sphaeropygini } \\
\text { Zettel } 1990 \\
\text { Pseudo- } \\
\text { phanerotomini } \\
\text { Zettel } 1990\end{array}$} & $\begin{array}{l}\text { Odontosphaeropyx Cameron } 1910 \\
\text { Pachychelonus Brues } 1924\end{array}$ & 6 & 3 & Afrotropical \\
\hline & Pseudophanerotoma Zettel 1990 & 7 & 3 & Nearctic \\
\hline & Furcidentia Zettel 1990 & 3 & 3 & \\
\hline & Dentigaster Zettel 1990 & 7 & 2 & Neotropical \\
\hline & Leptochelonus Zettel 1990 & 1 & 0 & Neotropical \\
\hline \multirow{7}{*}{$\begin{array}{l}\text { Phanerotomini } \\
\text { Baker } 1926\end{array}$} & Huseyinia Koçak \& Kemal 2008 & 1 & 1 & Neotropical \\
\hline & $\begin{array}{c}\text { Phanerotoma Wesmael } 1838 \\
\text { Bracotritoma Csiki } 1909\end{array}$ & 197 & 14 & Worldwide \\
\hline & Phanerotomella Szépligeti 1900 & 89 & 5 & Old World \\
\hline & Phanerotomoides Zettel 1990 & 1 & - & Neotropical \\
\hline & $\begin{array}{l}\text { Siniphanerotomella He, Chen \& van } \\
\text { Achterberg } 1994\end{array}$ & 2 & - & Oriental \\
\hline & Wushenia Zettel 1990 & 2 & - & Oriental \\
\hline & Phanaustrotoma Kittel \& Austin 2014 & 2 & 1 & Australasian \\
\hline \multirow{3}{*}{$\begin{array}{l}\text { Adeliini Viereck } \\
1918\end{array}$} & Adelius Haliday 1837 & 26 & 1 & Worldwide \\
\hline & Paradelius de Saeger 1942 & 5 & 1 & $\begin{array}{l}\text { Afrotropical, } \\
\text { Palaearctic, } \\
\text { Nearctic, } \\
\text { Oriental }\end{array}$ \\
\hline & Sinadelius He \& Chen 2000 & 2 & - & $\begin{array}{l}\text { Palaearctic, } \\
\text { Oriental }\end{array}$ \\
\hline
\end{tabular}


Table 2. Fossils used to calibrate the molecular clock, ordered by age of the deposits.

\begin{tabular}{lllll}
\hline Taxon & Reference & Deposit & Age range & Age reference \\
\hline Phanerotoma menieri & Belokobylskij & French amber & $52-53 \mathrm{Ma}$ & Nel et al., 1999 \\
& et al., 2010 & & & \\
Diodontogaster bidentata & Brues, 1933 & Baltic amber & $40-44 \mathrm{Ma}$ & Ritzkowski, 1997 \\
Ascogaster diletata & Brues, 1933 & Baltic amber & $40-44 \mathrm{Ma}$ & Ritzkowski, 1997 \\
Ascogaster gracilicornis & Brues, 1933 & Baltic amber & $40-44 \mathrm{Ma}$ & Ritzkowski, 1997 \\
Ascogaster pinicola & Brues, 1933 & Baltic amber & $40-44 \mathrm{Ma}$ & Ritzkowski, 1997 \\
Ascogaster praevolans & Brues, 1933 & Baltic amber & $40-44 \mathrm{Ma}$ & Ritzkowski, 1997 \\
Ascogaster pentagona & Brues, 1933 & Baltic amber & $40-44 \mathrm{Ma}$ & Ritzkowski, 1997 \\
Ascogaster robusta & Brues, 1933 & Baltic amber & $40-44 \mathrm{Ma}$ & Ritzkowski, 1997 \\
Ascogaster sylvetris & Brues, 1933 & Baltic amber & $40-44 \mathrm{Ma}$ & Ritzkowski, 1997 \\
Ascogaster submersa & Brues, 1933 & Baltic amber & $40-44 \mathrm{Ma}$ & Ritzkowski, 1997 \\
Phanerotoma baltica & Brues, 1933 & Baltic amber & $40-44 \mathrm{Ma}$ & Ritzkowski, 1997 \\
Phanerotoma extensa & Brues, 1933 & Baltic amber & $40-44 \mathrm{Ma}$ & Ritzkowski, 1997 \\
Chelonus depressus & Brues, 1910 & Florissant shale & $33-34 \mathrm{Ma}$ & McIntosh et al., 1992 \\
Chelonus muratus & Brues, 1910 & Florissant shale & $33-34 \mathrm{Ma}$ & McIntosh et al., 1992 \\
Chelonus solidus & Brues, 1910 & Florissant shale & $33-34 \mathrm{Ma}$ & McIntosh et al., 1992 \\
Eobracon cladurus & Cockerell, & White River & $28-35 \mathrm{Ma}$ & Emry, 1973 \\
& 1920 & & & \\
\hline
\end{tabular}

Table 3. List of primers used in this study.

\begin{tabular}{|c|c|c|c|}
\hline Gene & $\begin{array}{l}\text { Primer } \\
\text { name }\end{array}$ & Sequence $5^{\prime}-3^{\prime}$ & $\begin{array}{l}\text { Reference and annealing } \\
\text { Temp. }\end{array}$ \\
\hline COI & & & $47^{\circ} \mathrm{C}$ \\
\hline Forward 1 & CI-J-1718 & GGAGGATTTGGAAATTGATTAGTTCC & (Simon et al., 1994) \\
\hline Reverse 1 & CI-N-2191 & CCCGGTAAAATTAAAATATAAACTTC & (Simon et al., 1994) \\
\hline Reverse 2 & CI-N-2329 & ACTGTAAATATATGATGAGCTCA & (Simon et al., 1994) \\
\hline Forward 2 & M72 (L) & TGATTCTTCGGTCACCCAGAAGTGTA & (Georges et al., 1998) \\
\hline Reverse 3 & HCO2198 & TAAACTTCAGGGTGACCAAAAAATCA & (Folmer et al., 1994) \\
\hline EF1 $1 \alpha 2$ & & & $50^{\circ} \mathrm{C}$ \\
\hline Forward & ef $1 \alpha 1 \mathrm{~F}$ & AGATGGGYAARGGTTCCTTCAA & (Belshaw and Quicke, 1997) \\
\hline $\begin{array}{l}\text { Reverse } \\
\mathbf{2 8 S}\end{array}$ & efl $\alpha 1 \mathrm{R}$ & AACATGTTGTCDCCGTGCCATCC & $\begin{array}{l}\text { (Belshaw and Quicke, 1997) } \\
60{ }^{\circ} \mathrm{C}\end{array}$ \\
\hline Forward & 28S D2F & AGAGAGAGTTCAAGAGTACGTG & (Mardulyn and Whitfield, 1999) \\
\hline Reverse & 28S D3R & TAGTTCACCATCTTTCGGGTCCC & (Mardulyn and Whitfield, 1999) \\
\hline Forward & 2379 & BGGKCAGCGACGCTACTGCTTT & This study (first third) \\
\hline Reverse & 2380 & ATVCCCCRGGAATGCGAGAT & This study \\
\hline Forward & 2377 & DRAACCCCAAAGATCGAATGAGGAG & This study (second third) \\
\hline Reverse & 2378 & AGGRGAAGKGCRCGCCGACA & This study \\
\hline Forward & 2337 & GTCCGTGTTTCAAGACGGGTCC & This study (last third) \\
\hline Reverse & 2338 & TCGGCGTGCACTTCTYCYYTA & This study \\
\hline
\end{tabular}

Table 4. Markers, partition schemes, and substitution models according to Partitionfinder.

\begin{tabular}{llllll}
\hline Marker and partitions & \#bp & \#var & \#par & CG\% & Model \\
\hline COI mtDNA & 444 & 257 & 224 & 26.3 & \\
COI_1 & 148 & 73 & 63 & & TVM+I+ Г \\
\hline
\end{tabular}




\begin{tabular}{|c|c|c|c|c|c|}
\hline COI_2 & 148 & 46 & 35 & & $\overline{\mathrm{TVM}+\mathrm{I}+\mathrm{I}}$ \\
\hline COI_3 & 148 & 138 & 126 & & $\mathrm{HKY}+\mathrm{I}+\mathrm{I}$ \\
\hline EF1a F2 nuclear DNA & 378 & 148 & 108 & 41.3 & \\
\hline ef $1 \alpha \_1$ & 126 & 19 & 8 & & $\mathrm{GTR}+\mathrm{I}+\mathrm{I}$ \\
\hline ef1 $\alpha \_2$ & 126 & 15 & 2 & & $\mathrm{TVM}+\mathrm{I}+\mathrm{I}$ \\
\hline ef $1 \alpha \_3$ & 126 & 114 & 98 & & $\mathrm{TVM}+\mathrm{I}+\mathrm{I}$ \\
\hline 28S nuclear DNA & & & & & \\
\hline $\begin{array}{l}\text { 28S_123 } \\
\text { morphology }\end{array}$ & 632 & 469 & 357 & 40.9 & $\mathrm{GTR}+\mathrm{I}+\mathrm{I}$ \\
\hline $\begin{array}{l}\text { n/a } \\
\text { Combined morph and mol }\end{array}$ & 37 & 32 & 31 & $\mathrm{n} / \mathrm{a}$ & $\mathrm{Mk}+\Gamma$ \\
\hline $\begin{array}{l}\text { Combined morph and mol } \\
\text { Morphology, COI_1, COI_2, } \\
\text { COI_3, ef1 } \alpha \_1, \text { ef } 1 \alpha \_2, \\
\text { ef1 } \alpha \_3,28 S \_123\end{array}$ & 1491 & & & & $\begin{array}{l}\mathrm{Mk}+\mathrm{I} \\
\mathrm{GTR}+\mathrm{I}+\mathrm{I}\end{array}$ \\
\hline $\begin{array}{l}\text { concatenated } \\
\text { COI_1, COI_2, COI_3, } \\
\text { ef1 } 1 \alpha \_1, \text { ef } 1 \alpha \_2, \text { ef } 1 \alpha \_3, \\
28 S \_123\end{array}$ & 1454 & & & & $\mathrm{GTR}+\mathrm{I}+\mathrm{\Gamma}$ \\
\hline $\begin{array}{l}\text { Total-evidence with fossils } \\
\text { Morphology, COI_1\&2, } \\
\text { ef1 } 1 \& 2 \text {, ef1 } \alpha \_3,28 S \_123\end{array}$ & 1491 & & & & $\begin{array}{l}\mathrm{Mk}+\mathrm{I} \\
\mathrm{GTR}+\mathrm{I}+\mathrm{\Gamma}\end{array}$ \\
\hline
\end{tabular}

Table 5. Divergence-time estimates of three different dating approaches.

\begin{tabular}{|c|c|c|c|c|}
\hline Method & Median & lower & upper & priors \\
\hline \multicolumn{5}{|l|}{ Fixed-rate } \\
\hline & 47.39 & 29.57 & 73.04 & $\begin{array}{l}\text { Clockrate: } 1 \text { for } \mathrm{COI} \text { (translating to } 2.3 \% \\
\text { after the analysis) }\end{array}$ \\
\hline & 48.48 & 40.24 & 57.32 & $\begin{array}{l}\text { Clockrate: } 2.3 \% \text { for } \mathrm{CO1} \\
\text { tree-age prior: } \operatorname{gamma}(1,1)(\text { mean }=1)\end{array}$ \\
\hline & 93.42 & 70.90 & 120.74 & $\begin{array}{l}\text { Clockrate: of } 2.3 \% \text { for } C O 1, \text { tree-age } \\
\text { prior: gamma }(7,7)(\text { mean }=49)\end{array}$ \\
\hline & 138.74 & 92.05 & 205.51 & $\begin{array}{l}\text { Clockrate of } 2.3 \% \text { for } C O 1 \text {, root-age } \\
\text { prior: offexp }(52,72)\end{array}$ \\
\hline \multirow[t]{5}{*}{ Node-dating } & & & & Calibrations \\
\hline & 78.89 & 60.06 & 123.65 & $\begin{array}{l}\text { Root: offsetexp(72,130), Phanerotomini: } \\
\text { offsetexp }(52,72)\end{array}$ \\
\hline & 100.48 & 59.58 & 202.83 & $\begin{array}{l}\text { Root: offsetexp }(72,130) \text {, Phanerotomini: } \\
\text { offsetexp }(52,144)\end{array}$ \\
\hline & 84.03 & 59.27 & 143.76 & $\begin{array}{l}\text { Root: offsetexp }(72,260) \text {, Phanerotomini: } \\
\text { offsetexp }(52,72)\end{array}$ \\
\hline & 140.82 & 60.16 & 360.77 & $\begin{array}{l}\text { Root: offsetexp }(72,260) \text {, Phanerotomini: } \\
\text { offsetexp }(52,144)\end{array}$ \\
\hline \multicolumn{5}{|c|}{ Total-evidence } \\
\hline & 170.78 & 105.03 & 268.47 & Root: offsetexp $(72,130)$ \\
\hline & 205.72 & 122.59 & 368.06 & Root: offsetexp $(72,260)$ \\
\hline & 163.21 & 95.35 & 271.93 & $\begin{array}{l}\text { Root: offsetexp }(72,130) \text {, without } \\
\text { Phanerotoma menieri }\end{array}$ \\
\hline & 193.41 & 95.61 & 291.96 & $\begin{array}{l}\text { Root: offsetexp }(72,130) \text {, without } 1 / 3 \text { of } \\
\text { the morphological characters }\end{array}$ \\
\hline
\end{tabular}




\section{Figure legends.}

Figure 1. Bayesian consensus tree from the analysis of combined morphological and molecular data. The values under the nodes show the posterior probabilities from Bayesian, bootstrap of maximum likelihood, and bootstrap of parsimony analyses. A dash indicates that this clade was not present in the consensus tree. The squares depict the posterior probabilities of a Bayesian analysis of the individual partitions (morphology, COI, EFI $\alpha$, and 28S). A white square indicates that this branch was not present in the consensus tree. Lines show the position of Phanaustrotoma and Huseyinia embedded in Phanerotoma and Megascogaster in Ascogaster. Arrows show the placement of Baculonus (abbreviated BC), Carinichelonus (CA), and Scabrichelonus (SC) within Chelonus.

Figure 2. Placement of fossils in the Bayesian non-clock analysis of the combined morphological and molecular data. Fossils are marked as such. Numbers next to nodes show posterior probabilities.

Figure 3. Ranges of the $95 \%$ credibility intervals in the Bayesian node-dating analysis. Numbers next to nodes show posterior probabilities.

Figure 4. Correlation of morphological and molecular branch lengths. The branch lengths were calculated without the clock-assumption on the maximum a posteriori topology inferred in the totalevidence analysis. 


\section{Appendices}

Appendix 1. Species used in this study, with internal code/voucher number, country of origin and GenBank accession numbers. Annotations: • single sequence; $\bullet$ (Shi et al., unpublished); * (Murphy et al., 2008); (Kittel and Austin, 2015); * has been included, but is too short for a Genbank accession number.

\begin{tabular}{|c|c|c|c|c|c|}
\hline Taxon (code) & Voucher No. & Country & $\mathrm{COI}$ & EF1a & $28 S$ \\
\hline Adelius sp. & RK395 & France & KJ472526 & - & KJ472639 \\
\hline Ascogaster sp. (AS) & RK91 & South Korea & KJ472527 & KJ472584 & KJ472640 \\
\hline Ascogaster sp. (AS) & RK29 & Australia & KJ438543匹 & - & KJ472641 \\
\hline Ascogaster sp. (AS) & RK36 & Australia & - & KJ472585 & KJ472642 \\
\hline Ascogaster sp. (AS) & RK28 & Australia & KJ438541ロ & - & KJ472643 \\
\hline Ascogaster sp. (AS) & RK141 & Australia & KJ438561匹 & KJ472586 & KJ472644 \\
\hline Ascogaster sp. (AS) & RK167 & $\begin{array}{l}\text { New } \\
\text { Caledonia }\end{array}$ & KJ472528 & - & KJ472645 \\
\hline Ascogaster sp. (AS) & RK85 & Australia & KJ438636ロ & KJ472587 & KJ472646 \\
\hline Ascogaster sp. (AS) & RK88 & Australia & KJ472529 & KJ472588 & KJ472647 \\
\hline Ascogaster sp. (AS) & RK301 & Australia & KJ438554ロ & KJ472589 & KJ472648 \\
\hline Ascogaster sp. (AS) & RK168 & $\begin{array}{l}\text { New } \\
\text { Caledonia }\end{array}$ & KJ472530 & - & KJ472649 \\
\hline Ascogaster sp. (AS) & RK380 & Costa Rica & KJ472531 & KJ472590 & - \\
\hline Ascogaster sp. (AS) & RK379 & Costa Rica & KJ472532 & KJ472591 & KJ472650 \\
\hline Ascogaster sp. (AS) & RK385 & USA & KJ472533 & KJ472592 & - \\
\hline Ascogaster sp. (AS) & RK383 & USA & KJ472534 & KJ472593 & KJ472651 \\
\hline $\begin{array}{l}\text { Austroascogaster varia } \\
\text { Kittel \& Austin (AAG) }\end{array}$ & RK424 & Australia & KJ472535 & - & KJ472652 \\
\hline $\begin{array}{l}\text { Austroascogaster varia } \\
\text { (AAG)• }\end{array}$ & RK473 & Australia & - & - & $\sqrt{ } *$ \\
\hline Chelonus sp. (CH) & RK100 & Guatemala & KJ472536 & KJ472594 & KJ472653 \\
\hline Chelonus sp. (CH) & RK99 & Honduras & KJ472537 & KJ472595 & KJ472654 \\
\hline Chelonus sp. (MC) & RK217 & French Guiana & KJ472538 & - & KJ472655 \\
\hline Chelonus sp. (MC) & RK107 & Guatemala & - & KJ472596 & KJ472656 \\
\hline Chelonus sp. (MC) & RK392 & USA & - & KJ472597 & KJ472657 \\
\hline Chelonus sp. (CH) & RK384 & USA & - & $\sqrt{ } *$ & KJ472658 \\
\hline Chelonus sp. (CH) & RK221 & Gabon & KJ472539 & - & KJ472659 \\
\hline Chelonus sp. (CH) & RK102 & South Korea & KJ472540 & - & KJ472660 \\
\hline Chelonus sp. (MC) & RK109 & Thailand & KJ472541 & - & KJ472661 \\
\hline Chelonus sp. (CH) & RK387 & $\begin{array}{l}\text { Republic of } \\
\text { the Congo }\end{array}$ & KJ472542 & KJ472598 & KJ472662 \\
\hline Chelonus sp. (CH) & RK05 & Australia & KJ472543 & KJ472599 & KJ472663 \\
\hline
\end{tabular}




\begin{tabular}{|c|c|c|c|c|c|}
\hline Chelonus sp. (MC) & RK66 & Australia & KJ472544 & KJ472600 & KJ472664 \\
\hline Chelonus sp. (CH) & RK38 & Australia & KJ438520ロ & KJ472601 & KJ472665 \\
\hline Chelonus sp. (MC) & RK105 & Slovakia & KJ472545 & KJ472602 & KJ472666 \\
\hline Chelonus sp. (MC) & RK106 & Honduras & KJ472546 & KJ472603 & KJ472667 \\
\hline Chelonus sp. (MC) & RK142 & Australia & KJ472547 & KJ472604 & KJ472668 \\
\hline Chelonus sp. (MC) & RK20 & Australia & KJ472548 & KJ472605 & KJ472669 \\
\hline Chelonus sp. (MC) & RK76 & Australia & KJ472549 & KJ472606 & KJ472670 \\
\hline Chelonus sp. (MC) & RK110 & South Korea & KJ472550 & - & KJ472671 \\
\hline Chelonus sp. (CH) & RK389 & Costa Rica & KJ472551 & KJ472607 & KJ472672 \\
\hline Chelonus sp. (CH) & RK381 & Costa Rica & KJ472552 & - & KJ472673 \\
\hline Chelonus sp. (MC) & RK39 & Australia & KJ472553 & KJ472608 & KJ472674 \\
\hline Baculonus sp. (BC) & RK201 & French Guiana & KJ472554 & - & KJ472675 \\
\hline Baculonus sp. (BC) • & RK204 & French Guiana & - & - & KJ472676 \\
\hline Scabrichelonus sp. (SC) & RK397 & Vietnam & KJ472555 & KJ472609 & KJ472677 \\
\hline Carinichelonus sp. (CA) • & $\mathrm{n} / \mathrm{a}$ & China & - & - & AY973198 \\
\hline Dentigaster sp. (DG) & RK203 & French Guiana & KJ472556 & $\sqrt{ } *$ & KJ472678 \\
\hline Dentigaster sp. (DG) & RK214 & French Guiana & KJ472557 & KJ472610 & KJ472679 \\
\hline Huseyinia sp. (FI) & RK401 & French Guiana & KJ472558 & - & KJ472680 \\
\hline Leptodrepana sp. (LD) & RK96 & Costa Rica & KJ472561 & KJ472614 & KJ472683 \\
\hline Leptodrepana sp. (LD) & RK138 & USA & KJ472562 & KJ472615 & KJ472684 \\
\hline Leptodrepana sp. (LD) • & RK165 & Costa Rica & - & - & KJ472685 \\
\hline Leptodrepana sp. (LD) & RK391 & USA & KJ472563 & $\sqrt{ } *$ & KJ472686 \\
\hline Leptodrepana sp. (LD) & RK393 & USA & KJ472564 & KJ472616 & KJ472687 \\
\hline Leptodrepana sp. (LD) & RK378 & Sweden & KJ472565 & KJ472617 & KJ472688 \\
\hline Megascogaster sp. (MA) & RK422 & Indonesia & $\sqrt{ } *$ & - & KJ472689 \\
\hline Odontosphaeropyx sp. (PC) & RK399 & Tanzania & $\sqrt{ } *$ & - & KJ472690 \\
\hline $\begin{array}{l}\text { Odontosphaeropyx } \\
\text { leucocoxus Braet (PC) • }\end{array}$ & RK420 & Madagascar & $\sqrt{ } *$ & - & - \\
\hline $\begin{array}{l}\text { Odontosphaeropyx gracilis } \\
\text { Braet (PC) }\end{array}$ & RK421 & Madagascar & KJ472566 & - & KJ472691 \\
\hline Paradelius rubra (PD) & RK396 & USA & KJ472567 & KJ472618 & KJ472692 \\
\hline Phanerotomella sp. (PL) & RK131 & Madagascar & KJ472568 & KJ472619 & KJ472693 \\
\hline Phanerotomella sp. (PL) & RK170 & Madagascar & - & $\sqrt{ } *$ & KJ472694 \\
\hline Phanerotomella sp. (PL) & RK133 & Madagascar & KJ472569 & KJ472620 & KJ472695 \\
\hline $\begin{array}{l}\text { Phanerotomella variata } \\
\text { Kittel et al. (PL) }\end{array}$ & RK302 & Australia & KJ472570 & KJ472621 & KJ472696 \\
\hline Phanerotomella sp. (PL) & RK122 & Thailand & KJ472571 & KJ472622 & KJ472697 \\
\hline
\end{tabular}




\begin{tabular}{|c|c|c|c|c|c|}
\hline $\begin{array}{l}\text { Phanaustrotoma pallida } \\
\text { Kittel \& Austin (PAT) }\end{array}$ & RK426 & Australia & $\sqrt{ } *$ & - & KJ472698 \\
\hline Phanerotoma sp. (PH) & RK119 & Costa Rica & KJ472572 & KJ472623 & KJ472699 \\
\hline Phanerotoma sp. (PH) & RK124 & $\begin{array}{l}\text { Republic of } \\
\text { the Congo }\end{array}$ & KJ472573 & KJ472624 & KJ472700 \\
\hline Phanerotoma sp. (PH) & RK136 & USA & KJ472574 & KJ472625 & KJ472701 \\
\hline Phanerotoma sp. (PH) & RK113 & Mexico & KJ472575 & KJ472626 & KJ472702 \\
\hline Phanerotoma sp. (PH) & RK261 & Australia & KJ438631匹 & KJ472627 & KJ472703 \\
\hline Phanerotoma sp. (PH) & RK123 & South Korea & KJ472576 & KJ472628 & KJ472704 \\
\hline Phanerotoma sp. (PH) & RK403 & South Korea & KJ472577 & KJ472629 & KJ472705 \\
\hline Phanerotoma sp. (PH) & RK402 & South Korea & KJ472578 & KJ472630 & KJ472706 \\
\hline Phanerotoma sp. (PH) & RK405 & South Korea & KJ472579 & KJ472631 & KJ472707 \\
\hline Phanerotoma sp. (PH) & RK02 & Australia & KJ438586ロ & KJ472632 & KJ472708 \\
\hline Phanerotoma sp. (PH) & RK250 & Australia & KJ438601 & KJ472633 & KJ472709 \\
\hline $\begin{array}{l}\text { Phanerotoma behriae Zettel } \\
(\mathrm{PH})\end{array}$ & RK01 & Australia & KJ438611 & KJ472634 & KJ472710 \\
\hline Phanerotoma behriae (PH) & RK171 & Australia & KJ438616 & KJ472635 & KJ472711 \\
\hline Phanerotoma sp. (PH) & RK135 & USA & KJ472580 & KJ472636 & KJ472712 \\
\hline $\begin{array}{l}\text { Pseudophanerotoma sp. } \\
\text { (PP) }\end{array}$ & RK218 & French Guiana & KJ472581 & - & KJ472713 \\
\hline $\begin{array}{l}\text { Pseudophanerotoma sp. } \\
\text { (PP) }\end{array}$ & RK314 & French Guiana & KJ472582 & - & KJ472714 \\
\hline $\begin{array}{l}\text { Pseudophanerotoma sp. } \\
\text { (PP) }\end{array}$ & RK114 & Guatemala & KJ472583 & KJ472637 & KJ472715 \\
\hline $\begin{array}{l}\text { Pseudophanerotoma } \\
\text { (Furcidentia) sp. (LC) • }\end{array}$ & RK115 & Guatemala & - & KJ472611 & - \\
\hline $\begin{array}{l}\text { Pseudophanerotoma } \\
\text { (Furcidentia) sp. (LC) }\end{array}$ & RK116 & Guatemala & KJ472559 & KJ472612 & KJ472681 \\
\hline $\begin{array}{l}\text { Pseudophanerotoma } \\
\text { (Furcidentia) sp. (LC) }\end{array}$ & RK315 & French Guiana & KJ472560 & KJ472613 & KJ472682 \\
\hline $\begin{array}{l}\text { Microgastrinae (Microplitis } \\
\text { sp.) }\end{array}$ & JW58 & Australia & - & KJ472638 & KJ472716 \\
\hline Ichneutinae (Ichneutes sp.) & M124 & USA & EU106967• & EU106996* & EU106928* \\
\hline Euphorinae (Leiophron sp.) & JW56 & Australia & EU106964* & EU106993* & EU106925 * \\
\hline Miracinae (Mirax sp.) & JW65 & Australia & EU106971* & EU106999* & EU106929* \\
\hline
\end{tabular}

Appendix 2. List of morphological characters and their character states.

\begin{tabular}{|c|c|}
\hline Character & Character state \\
\hline 1. Teeth on clypeus & $\begin{array}{l}\text { 1. absent, } 2 \text {. one tooth present, } 3 \text {. two teeth present, } 4 \text {. three } \\
\text { teeth present }\end{array}$ \\
\hline $\begin{array}{l}\text { 2. Mandible with a transverse } \\
\text { carina }\end{array}$ & 1. absent, 2. present \\
\hline $\begin{array}{l}\text { 3. Occipital carina touching } \\
\text { hypostomal carina }\end{array}$ & 1. absent, 2. present \\
\hline 4. Temple & 1. swollen, 2. not swollen \\
\hline 5. Shape of eyes & 1. oval, 2. round \\
\hline 6. Hairs on eyes & 1. glabrous, 2 . densely setose \\
\hline
\end{tabular}




7. Number of female antennomeres
8. Arrangement of ocelli

9. Occipital carina

10. Notauli

11. Precoxal sulcus

12. Blister on mesotibia

13. Teeth on claws

14. Prepectal carina

15. Postpectal carina

16. Vein $\mathrm{r}-\mathrm{m}$ of fore wing

17. $\mathrm{r}$ in fore wing

18. $1-\mathrm{SR}+\mathrm{M}$

19. $2-\mathrm{SR}+\mathrm{M}$

20. 1-cu 1

21. CU1b

22. SR-1 (+3-SR)

23. $(\mathrm{SR} 1+) 3-\mathrm{SR}$

24. $\mathrm{R}$

25. 2-R1

26. Second cubital cell

27. Ratio of pterostigma to $1-\mathrm{R} 1$ :

28. $\mathrm{r}$ in hind wing

29. Carapace (fused metasomal tergites 1-3)

30. Sutures on metasoma

31. Posterior pit in males

32. Tip of carapace

33. Shape of metasoma in lateral view

34. Shape of metasoma in dorsal view

35. Pairs of abdominal spiracles

36. Metasoma is attached to the

Mesosoma by

37. Spiracles of first metasomal tergite
1. $16,2.17-22,3.23,4.24$ or more

1. equilateral, 2. isosceles 'on line', where an imaginary line between anterior margin of posterior ocelli is sometimes touching anterior ocellus, 3 . isosceles 'not on line', where and imaginary line between anterior margin of posterior ocelli not touching anterior ocellus

1. complete, 2 . reduced/dorsally absent

1. absent, 2. present

1. absent, 2. present

1. absent, 2. present

1. absent, 2. present

1. absent; 2 . completely present, 3 . partly present

1. absent, 2. short ventral part present, 3. complete

1. absent, 2. sclerotised, 3. unsclerotised

1. absent, 2. present

1. absent, 2. present, from parastigma, 3. present, from 1-M

1. antefurcal, 2. interstitial, 3. postfurcal

1. antefurcal, 2. interstitial, 3. postfurcal

1. absent (subdiscal cell open), 2. present (subdiscal cell closed)

1. complete (sclerotised), 2. incomplete (not sclerotised)

1. absent, 2. present as SR1+3-SR (interstitial), 3. two present as SR1 and 3-SR (antefurcal), 4. two present as SR1 and 3-SR (postfurcal)

1. extending to apex of wing, 2. not extending to apex of wing

1. absent, 2. present

1. at least half the length of first, 2. reduced or much shorter than half of first cell, 3. about half as long as first

1. same length, 2. much longer, 3 . shorter

1. absent, 2. present

1. absent, 2. present, 3. partly fused

1. absent, 2. present

1. absent, 2. present

1. round, 2. with one central spike, 3. with lobes, 4. with two or four lateral teeth, 5 . membranous

1. posteriorly bent under, 2. flat, 3 . broad

1. round, 2. elongate/ parallel-sided, 3. oval, 4. with petiole

1. 4 pairs, 2.5 pairs, 3.6 pairs, 4.7 or more pairs

1. a sclerotised median plate, 2 . a membranous part of tergum

1. in notum, 2. in epipleuron

Appendix 3. List of coded character states per species used in the morphological and totalevidence analyses, in alphabetical order by genera.

\begin{tabular}{ll}
\hline Species name & Morphological codings \\
\hline & 000000000111111111222222222233333333 \\
Adelius & 1234567890123456789012345678901234567 \\
AD_RK395 & $112212 ? 311211111123212121221211523211$ \\
\hline
\end{tabular}




\begin{tabular}{|c|c|}
\hline \multicolumn{2}{|l|}{ Ascogaster } \\
\hline AS_SK_RK91 & $212211 ? 212211233231321321211211133211$ \\
\hline AS_AUS_RK29 & 1122114312211233222321321221211133211 \\
\hline AS_AUS_RK36 & 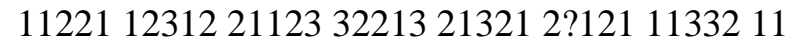 \\
\hline AS_AUS_RK28 & $112211431121123322 ? 321322211211133211$ \\
\hline AS_AUS_RK141 & $112211 ? 312211233221321321211211133211$ \\
\hline AS_NC_RK167 & $112211 ? 112211233222321321221211133211$ \\
\hline AS_AUS_RK85 & 1112114312211233221321321221211133211 \\
\hline AS_sp_RK88 & $11 ? 21 \quad 1 ? 212 \quad ? 11233231321322211211213211$ \\
\hline AS_AUS_RK301 & 3112114312111233222321321221211133211 \\
\hline AS_NC_RK168 & $11 ? 21 \quad 1 ? 31221123322132232123121 \quad 1133211$ \\
\hline AS_CR_RK380 & $112211 ? 312211233231321321221211133211$ \\
\hline AS_CR_RK379 & $11 ? 21 \quad 1 ? 212211233233321321211211133211$ \\
\hline AS_USA_RK385 & $112211 ? 212111233233321321221211113211$ \\
\hline AS_USA_RK383 & 1122114212111233233321321211211113211 \\
\hline Ascogaster_diletata_fossil & ???21 1421? ?1123 32??3 2132? 2?121 11?32 11 \\
\hline Ascogaster_gracilicornis_fossil & ???21 1 ??212 ?1123 32??3 2132? 2?121 11 ?32 11 \\
\hline Ascogaster_pinicola_fossil & ???21 12212 ?1123 $32 ? ? 32132 ? 2 ? 12111 ? 3211$ \\
\hline Ascogaster_praevolans_fossil & ???21 14212 ?1123 32??3 2132? 2?121 11 ?32 11 \\
\hline Ascogaster_pentagona_fossil & ???21 14212 ?1123 $32 ? ? 32132 ? 2 ? 12111 ? 3211$ \\
\hline Ascogaster_robusta_fossil & ???21 14212 ?1123 $323332131 ? 2 ? 12111 ? 3211$ \\
\hline Ascogaster_sylvetris_fossil & ???21 14212 ?1123 $32 ? ? 32132 ? 2 ? 12111 ? 3211$ \\
\hline Ascogaster_submersa_fossil & ???21 14212 ?1123 $32 ? ? 32132 ? 2 ? 12111 ? 3211$ \\
\hline \multicolumn{2}{|l|}{ Austroascogaster } \\
\hline AAG_AUS_RK424 & 1122114321211233223321321211211133211 \\
\hline AAG_AUS_RK473 & 1122114321211233223321321211211133211 \\
\hline \multicolumn{2}{|l|}{ Chelonus } \\
\hline CH_GUA_RK100 & $111212 ? 31211123321 ? 32132221121$ ?1332 11 \\
\hline CH_HON_RK99 & $111212 ? 21211123321 ? 32132221121$ ?1132 11 \\
\hline MC_FRG_RK217 & $11 ? 212 ? 31221123321 ? 321321221212133211$ \\
\hline MC_GUA_RK107 & $111212131211123321 ? 32132222121$ ?1332 11 \\
\hline MC_USA_RK392 & $11 ? 212 ? 31221123321 ? 32132122121$ ?332 11 \\
\hline CH_USA_RK384 & $111212 ? 31221123321 ? 32132122121$ ?1132 11 \\
\hline CH_GAB_RK221 & $11121213 ? 211123321 ? 32132121121$ ?1132 11 \\
\hline CH_SK_RK102 & $111212 ? 3 ? 221123321 ? 32132221121$ ?1132 11 \\
\hline MC_THA_RK109 & $11 ? 21$ ?1312 $11123321 ? 32132121121$ ?4332 11 \\
\hline CH_ROC_RK387 & $11 ? 212 ? 21211123321 ? 32132 ? 2 ? 121$ ?1332 11 \\
\hline CH_AUS_RK05 & $11 ? 21$ ??312 $21123321 ? 321322221211113211$ \\
\hline MC_sp_RK66 & $11 ? 2121311$ ?1123 $321 ? 321321221212 ? 33211$ \\
\hline CH_sp_RK38 & $11 ? 212 ? 312$ ?1123 $321 ? 32132222121$ ?132 11 \\
\hline MC_SLO_RK105 & $11 ? 212 ? 31221123321 ? 321322221212 ? 13211$ \\
\hline MC_HON_RK106 & $11 ? 212121221123321 ? 32132222121 ? 133211$ \\
\hline MC_AUS_RK142 & 11121 ??312 $11123321 ? 321322221212113211$ \\
\hline MC_AUS_RK20 & $111211131211123321 ? 32132222121 ? 133211$ \\
\hline CH_AUS_RK76 & $11121 ? 131211123321 ? 32132222121$ ????2 11 \\
\hline MC_SK_RK110 & $11 ? 212131221123321 ? 32 ? 32222121$ ?332 11 \\
\hline CH_CR_RK389 & $11 ? 212 ? 31221123321 ? 32132122121$ ?332 11 \\
\hline MC_CR_RK381 & $111212131221123321 ? 32132122121 ? 113211$ \\
\hline CH_AUS_RK39 & $11 ? 211431211123321 ? 32132122121 ? 113211$ \\
\hline BC_FRG_RK201 & $11 ? 212131221123321 ? 32132122121 ? 133211$ \\
\hline BC_sp_RK204 & $111212131121123321 ? 32132221121 ? 133211$ \\
\hline SC_sp_RK397 & $11 ? 112 ? 31211123321 ? 32132222121$ ?1322 11 \\
\hline Chelonus_depressus_fossil & 1??21 ???1? ?1123 $321 ? 32132 ? 2 ? 121$ ?1?32 11 \\
\hline Chelonus_muratus_fossil & 1??21 ???1? ?1123 $321 ? 32132 ? 2 ? 121$ ?1?32 11 \\
\hline Chelonus_solidus_fossil & 1??21 ???1??1123 $321 ? 32132 ? 2 ? 121$ ?1?32 11 \\
\hline
\end{tabular}




\begin{tabular}{|c|c|}
\hline \multicolumn{2}{|l|}{ Dentigaster } \\
\hline DG_sp_RK203 & $31 ? 21 \quad 1 ? 112111233223321322311221433211$ \\
\hline DG_FRG_RK214 & ?1??2 ????? ??123 32??3 2?3?? ??122 1???2 11 \\
\hline \multicolumn{2}{|l|}{ Diodontogaster } \\
\hline $\begin{array}{l}\text { Diodontogaster_bidentata_fossil } \\
\text { Eobracon }\end{array}$ & $11 ? 2114 ? ? 2 ? 11233233321311221211433211$ \\
\hline Eobracon_cladurus_fossil & ?1?2? ????? ?1123 $322132131123 ? 2111 ? 3211$ \\
\hline \multicolumn{2}{|l|}{ Fischeriella } \\
\hline FI_sp_RK401 & $31 ? 221 ? 112121233222321312231221523211$ \\
\hline \multicolumn{2}{|l|}{ Furcidentia } \\
\hline LC_GUA_RK115 & $112221 ? 1 ? 2221233223321311231221323211$ \\
\hline LC_sp_RK116 & $112221 ? 112221233233321311211221323211$ \\
\hline LC_FRG_RK315 & 1122214112221233223221311231221323211 \\
\hline \multicolumn{2}{|l|}{ Leptodrepana } \\
\hline LD_CR_RK96 & 1122112112111233231321321221211433211 \\
\hline LD_USA_RK138 & $11 ? 21121 ? 2111233232321321221211433211$ \\
\hline LD_CR_RK165 & 1122112122211233221321321221211233211 \\
\hline LD_USA_RK391 & $112211 ? 122211233232321321221211133211$ \\
\hline LD_USA_RK393 & $11 ? 21 \quad 1 ? 122211233232321321211211132211$ \\
\hline LD_SWE_RK378 & $112211 ? 31221123323 ? 3213212 ? 121 \quad 1132211$ \\
\hline \multicolumn{2}{|l|}{ Megascogaster } \\
\hline MA_IND_RK422 & 3122119322211233221321322321211232211 \\
\hline \multicolumn{2}{|l|}{ Pachychelonus } \\
\hline PC_sp_RK399 & 2122114112112233231321321332221113211 \\
\hline PC_leucocoxus_RK420 & 2122114112212233231321322312221132211 \\
\hline PC_gracilis_RK421 & $21 ? 2214112212233231321321312221132211$ \\
\hline \multicolumn{2}{|l|}{ Paradelius } \\
\hline PA_RK396 & $112212 ? 311211111133212121221221523211$ \\
\hline \multicolumn{2}{|l|}{ Phanerotomella } \\
\hline PL_MAD_RK131 & 1122214111111233223311422231221323211 \\
\hline PL_MAD_RK170 & $11 ? 2214111111233223311422231221323211$ \\
\hline PL_MAD_RK133 & $1122214112111233223311422221221 ? ? ? 211$ \\
\hline PL_variata_sp_nov_RK302 & $11 ? 2213111$ ?1123 3223311222211221323211 \\
\hline PL_THA_RK122 & 1122214111111233223311422211221323211 \\
\hline \multicolumn{2}{|l|}{ Phanaustrotoma } \\
\hline PAT_AUS_RK426 & 3122213112111233223311311231221122211 \\
\hline \multicolumn{2}{|l|}{ Phanerotoma } \\
\hline PH_CR_RK119 & 3122213112121233222321311231221423211 \\
\hline PH_ROC_RK124 & $41 ? 2213112221233222321311231221123211$ \\
\hline PH_sp_RK136 & $41 ? 2213121$ ?2123 3222321311231221123211 \\
\hline PH_MEX_RK113 & $31 ? 2213112221233223321312211221323211$ \\
\hline PH_AUS_RK261 & 3122213112221233221321311231221323211 \\
\hline PH_SK_RK123 & $31222131122212332223213122 ? 1221423211$ \\
\hline PH_SK_RK403 & 4122213112121233222321311231221323211 \\
\hline PH_SK_RK402 & $41 ? 2213112221233222321311211221123211$ \\
\hline PH_SK_RK405 & $31 ? 2213112111233222321311231221123211$ \\
\hline PH_AUS_RK02 & $31 ? 2213112221233222321311231221423211$ \\
\hline PH_AUS_RK250 & 3122213112221233222321311231221423211 \\
\hline PH_sp_RK01 & $41 ? 2213111$ ?2123 3222321311231221323211 \\
\hline PH_AUS_RK171 & 4122213111221233222321311231221323211 \\
\hline PH_USA_RK135 & 4122213112221233222321311231221123211 \\
\hline Phanerotoma_baltica_fossil & ???21 ?4?12 ??123 $32 ? 33$ ?13?? ??122 1??32 11 \\
\hline Phanerotoma_extensa_fossil & ???21 14 ?12 ??123 $32 ? 33$ ?13?? ??122 1??32 11 \\
\hline Phanerotoma_menieri_fossil & 3??22 14?12 1?123 3223121311 ??122 1??32 11 \\
\hline Pseudophanerotoma & \\
\hline
\end{tabular}




\begin{tabular}{ll}
\hline PP_FRG_RK218 & 3112214112221233233321311131221123211 \\
PP_FRG_RK314 & $311221 ? 112221233233321311131221123211$ \\
PP_sp_RK114 & $11 ? 221 ? 112 ? 11233233321311331221123211$ \\
Outgroups & \\
Euphorinae_JW56 (Leiophron sp.) & $1 ? ? 221 ? 112 ? 1111 ? 232 ? 1122221131113442 ?$ \\
Ichneutinae_M124 (Ichneutes sp.) & $1 ? ? 221 ? 122 ? 1111 ? 121 ? 2132221111112342 ?$ \\
Miracinae_JW65 (Mirax sp.) & $1 ? ? 221 ? 111 ? 1111 ? 231 ? 21221221111133222$ \\
Microgastrinae (Microplitis sp.) & ????? ????? ????? ????? ????? ????? ????? ?? \\
\hline
\end{tabular}

Appendix 4. Replacement names for homonyms and secondary homonyms.

\begin{tabular}{|c|c|c|}
\hline Senior homonym & Junior homonym & $\begin{array}{l}\text { Replacement name for junior } \\
\text { homonym }\end{array}$ \\
\hline $\begin{array}{l}\text { Chelonus (Chelonus) } \\
\text { angustiventris Tobias, } 1974\end{array}$ & $\begin{array}{l}\text { Chelonus (Microchelonus) } \\
\text { angustiventris Tobias, } 1986\end{array}$ & $\begin{array}{l}\text { Chelonus fionae nom. nov. } \\
\text { Kittel }\end{array}$ \\
\hline $\begin{array}{l}\text { Chelonus (Microchelonus) } \\
\text { apicalis Papp,1971 }\end{array}$ & $\begin{array}{l}\text { Chelonus (Chelonus) apicalis } \mathrm{Ji} \\
\& \text { Chen, } 2003\end{array}$ & Chelonus yani nom. nov. Kittel \\
\hline $\begin{array}{l}\text { Chelonus (Chelonus) bicolorus } \\
\text { Chen \& Ji,2003 }\end{array}$ & $\begin{array}{l}\text { Chelonus (Chelonus) bicolorus } \\
\mathrm{He}, 2003\end{array}$ & $\begin{array}{l}\text { Chelonus billyi nom. nov. } \\
\text { Kittel }\end{array}$ \\
\hline $\begin{array}{l}\text { Chelonus (Microchelonus) } \\
\text { brevicornis McComb, } 1968\end{array}$ & $\begin{array}{l}\text { Chelonus (Microchelonus) } \\
\text { brevicornis Tobias, } 1989\end{array}$ & $\begin{array}{l}\text { Chelonus spikei nom. nov. } \\
\text { Kittel }\end{array}$ \\
\hline $\begin{array}{l}\text { Chelonus (Microchelonus) } \\
\text { depressus Thomson, } 1874\end{array}$ & $\begin{array}{l}\text { Chelonus (Chelonus) depressus } \\
\text { Brues, } 1910\end{array}$ & $\begin{array}{l}\text { Chelonus williami nom. nov. } \\
\text { Kittel }\end{array}$ \\
\hline $\begin{array}{l}\text { Chelonus (Chelonus) elongatus } \\
\text { Szépligeti, } 1898\end{array}$ & $\begin{array}{l}\text { Chelonus (Stylochelonus) } \\
\text { elongatus Papp, } 1971\end{array}$ & $\begin{array}{l}\text { Chelonus ragnhildae nom. nov. } \\
\text { Kittel }\end{array}$ \\
\hline $\begin{array}{l}\text { Chelonus (Chelonus) fischeri } \\
\text { Huddleston \& Walker,1994* }\end{array}$ & $\begin{array}{l}\text { Chelonus (Microchelonus) } \\
\text { fischeri Tobias, } 1994^{*}\end{array}$ & Chelonus larsi nom. nov. Kittel \\
\hline $\begin{array}{l}\text { Chelonus (Chelonus) } \\
\text { immaculatus Cameron, } 1905\end{array}$ & $\begin{array}{l}\text { Chelonus (Chelonus) } \\
\text { immaculatus He, } 1994\end{array}$ & $\begin{array}{l}\text { Chelonus arthuri nom. nov. } \\
\text { Kittel }\end{array}$ \\
\hline $\begin{array}{l}\text { Chelonus (Chelonus) iranicus } \\
\text { Tobias, } 1972\end{array}$ & $\begin{array}{l}\text { Chelonus (Microchelonus) } \\
\text { iranicus Tobias, } 2001\end{array}$ & Chelonus robi nom. nov. Kittel \\
\hline $\begin{array}{l}\text { Chelonus (Microchelonus) } \\
\text { kaszabi Tobias, } 1989\end{array}$ & $\begin{array}{l}\text { Chelonus (Chelonus) kaszabi } \\
\text { Papp, } 1992\end{array}$ & $\begin{array}{l}\text { Chelonus wullii nom. nov. } \\
\text { Kittel }\end{array}$ \\
\hline $\begin{array}{l}\text { Chelonus (Chelonus) } \\
\text { mediterraneus Schmiedeknecht } \\
\text { \& Fahringer, } 1934\end{array}$ & $\begin{array}{l}\text { Chelonus (Microchelonus) } \\
\text { mediterraneus Tobias, } 2008\end{array}$ & $\begin{array}{l}\text { Chelonus hamishi nom. nov. } \\
\text { Kittel }\end{array}$ \\
\hline $\begin{array}{l}\text { Chelonus (Microchelonus) } \\
\text { minutissima Tobias, } 1964\end{array}$ & $\begin{array}{l}\text { Chelonus (Areselonus) } \\
\text { minutissima Braet,1999 }\end{array}$ & $\begin{array}{l}\text { Chelonus pauli nom. nov. } \\
\text { Kittel }\end{array}$ \\
\hline $\begin{array}{l}\text { Chelonus (Microchelonus) } \\
\text { nigripes Rao \& Chalikwar,1971 }\end{array}$ & $\begin{array}{l}\text { Chelonus (Microchelonus) } \\
\text { nigripes Tobias, } 1996\end{array}$ & $\begin{array}{l}\text { Chelonus jeannieae nom. nov. } \\
\text { Kittel }\end{array}$ \\
\hline
\end{tabular}




\begin{tabular}{lll}
\hline $\begin{array}{l}\text { Chelonus (Chelonus) } \\
\text { scrobiculatus Szépligeti,1900 }\end{array}$ & $\begin{array}{l}\text { Chelonus (Microchelonus) } \\
\text { scrobiculatus Tobias,1986 }\end{array}$ & $\begin{array}{l}\text { Chelonus aggieae nom. nov. } \\
\text { Kittel }\end{array}$ \\
$\begin{array}{l}\text { Chelonus (Microchelonus) } \\
\text { ubsunuricus Tobias,1996 }\end{array}$ & $\begin{array}{l}\text { Chelonus (Chelonus) } \\
\text { ubsunuricus Tobias,2011 }\end{array}$ & Chelonus jocki nom. nov. Kittel \\
$\begin{array}{l}\text { Chelonus (Megachelonus) } \\
\text { uniformis Baker,1926 }\end{array}$ & $\begin{array}{l}\text { Chelonus (Microchelonus) } \\
\text { uniformis Tobias,1994 }\end{array}$ & $\begin{array}{l}\text { Chelonus tamkeae nom. nov. } \\
\text { Kittel }\end{array}$ \\
\hline
\end{tabular}

* Huddleston \& Walker (1994) is treated as the senior homonym (see article 24.2 of the ICZN code). 


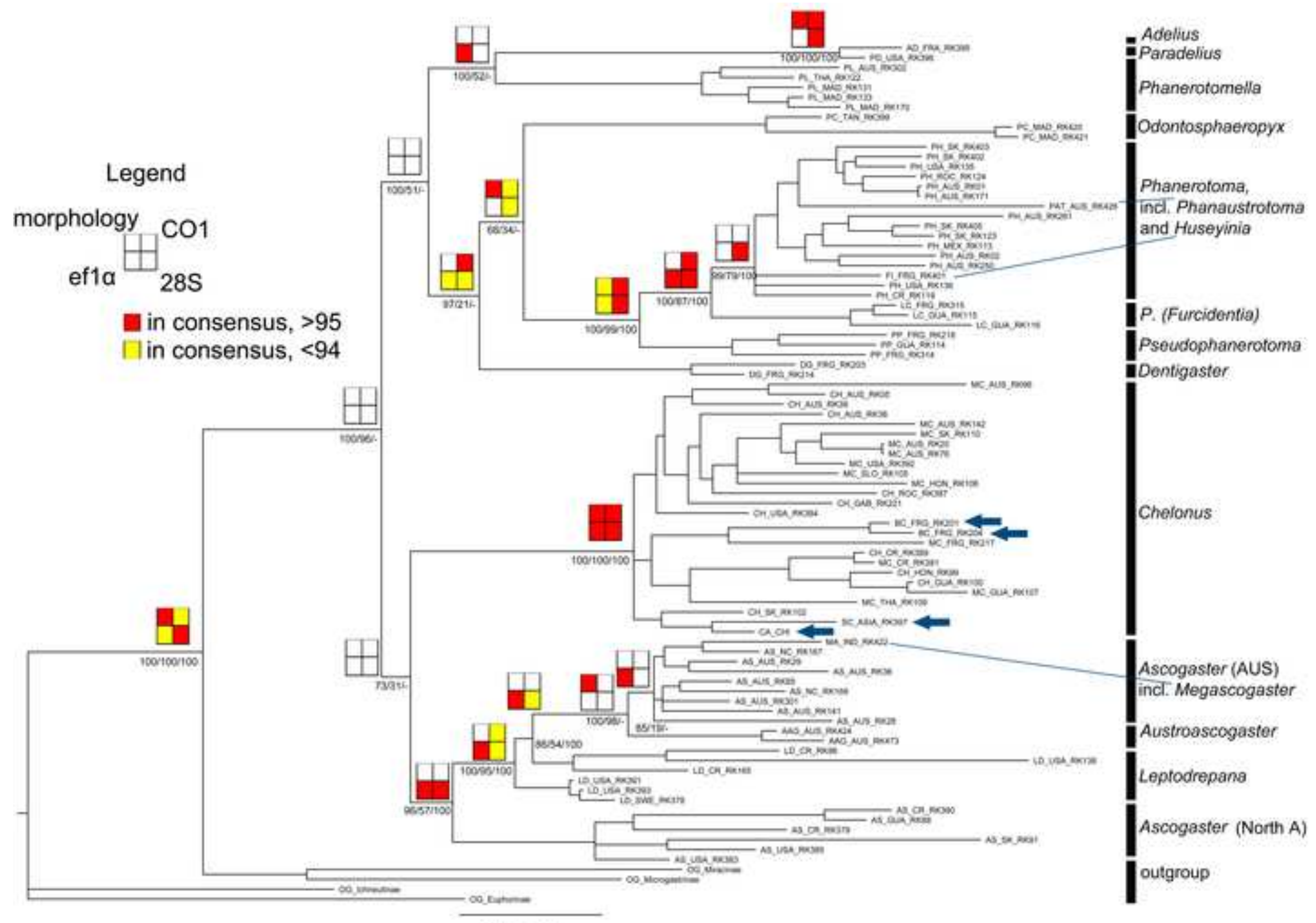

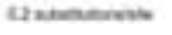




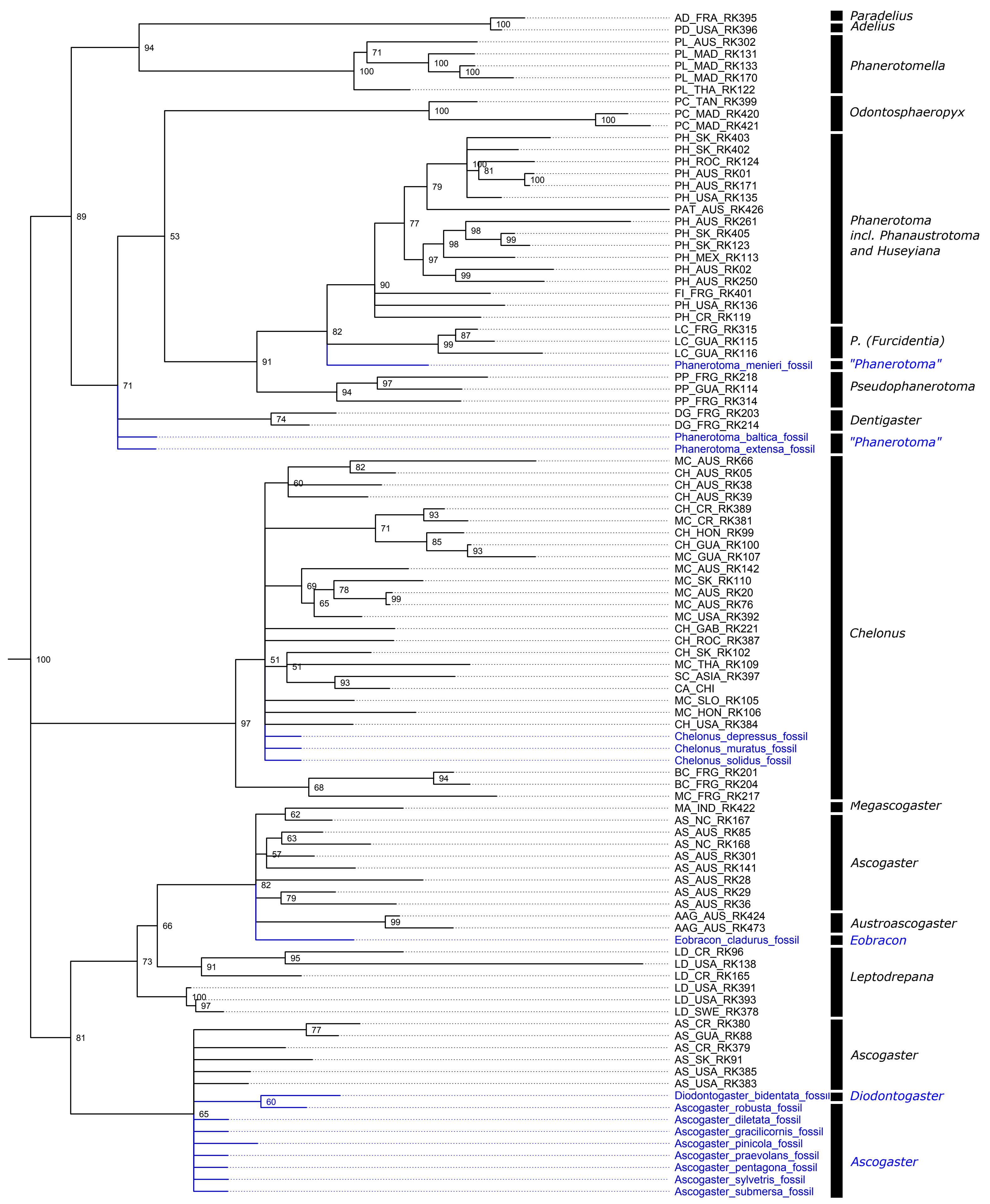


comparison of molecular versus morphological branch lengths

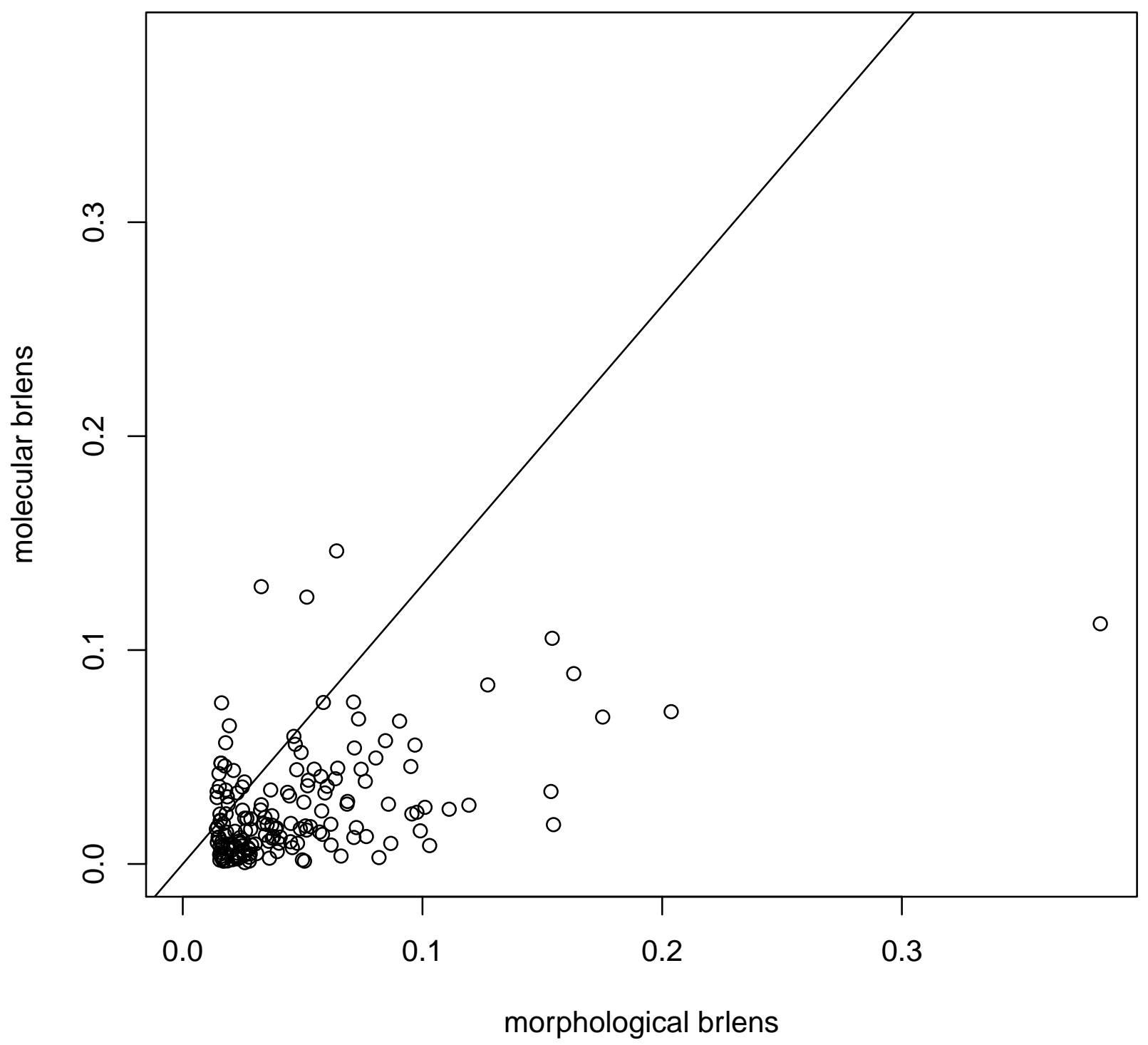




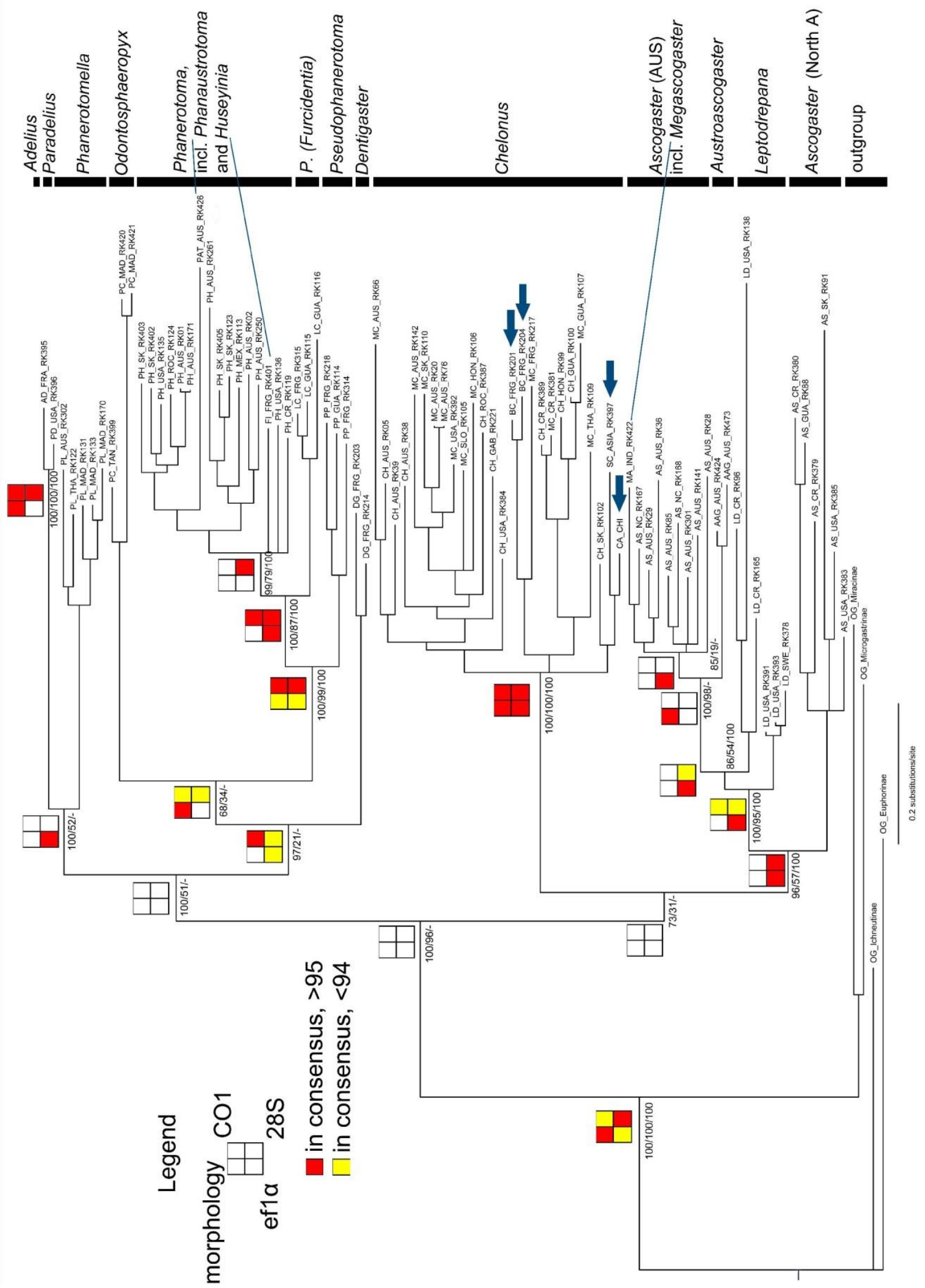

